\title{
Time-dependent Thermoelectric Power of Diopside
}

\author{
J. Stephen Huebner \\ U.S. Geological Survey \\ 955 National Center \\ Reston, Virginia 20192
}

U.S. Geological Survey Open File Report 97-479

This report is preliminary and has not been reviewed for conformity with U.S. Geological Survey editorial standards. Any use of trade names is for descriptive purposes only and does not imply endorsement by the U.S. Geological Survey. 


\begin{abstract}
The thermoelectric power coefficient $(\mathrm{Q}=-\mathrm{dV} / \mathrm{dK})$ was measured in the [001] direction of a diopside crystal surrounded by silica glass. The diopside has composition $\mathrm{Ca}_{1983}(\mathrm{Na}, \mathrm{Mn}, \mathrm{Zn})_{9}$ $(\mathrm{Mg}, \mathrm{Fe}, \mathrm{Ni}, \mathrm{Cr})_{1010}(\mathrm{Al}, \mathrm{Ti}, \mathrm{P})_{2} \mathrm{Si}_{1994} \mathrm{O}_{6000}$ and atomic Ca:Mg:Fe of 495:482:23. The oxygen fugacity ranged from that of the iron-wüstite assemblage to a factor more than $10^{4}$ greater, and the temperature gradient was $1.5-5 \mathrm{~K}$ over $0.0176 \mathrm{~m}$. Initially, steady-state values of $\mathrm{Q}$ were -2 and $6 \mathrm{mV} / \mathrm{K}$ at 1173 and $1273 \mathrm{~K}$, respectively, and independent of $f \mathrm{o}_{2}$. At $1371 \mathrm{~K}, \mathrm{Q}$ was $\approx-10 \mathrm{mV} / \mathrm{K}$ but unstable. These results suggest that negative charge carriers are dominant. Impedance spectroscopy, using metal electrodes, suggests that some charge carriers cross the interface between diopside and the platinum electrodes.
\end{abstract}

Before steady-state, $\mathrm{Q}$ is sensitive to the recent redox history of the sample. Increasing the $\mathrm{fo}_{2}$ by $\times 10^{4}$ (within 250 seconds) caused Q to become more negative (at $1170-6000 \mathrm{~s}$ ), then rise slowly (more than $20,000 \mathrm{~s}$ ) to the original negative value. Decreasing the $\mathrm{fo}_{2}$ caused Q quickly to become more positive $\left(Q_{\max }\right.$ at 1260 - $\left.1860 \mathrm{~s}\right)$, then decrease slowly to the original negative value. Most values of $\mathrm{Q}_{\max }$ were positive, suggesting a temporary change in the sign of the dominant charge carrier(s). Q of the silica glass sleeve in a larger (49-62K) thermal gradient was positive but always $<1 \mathrm{mV} / \mathrm{K}$. In six cases, a large change in $f \mathrm{o}_{2}$ caused $\mathrm{Q}$ to change, temporarily, with $\mathrm{fo}_{2}$, and in three cases the temporary change in $\mathrm{Q}$ was opposite to the direction of $\mathrm{fo}_{2}$ change. When the same diopside crystal was subsequently measured alone in a $14-18 \mathrm{~K}$ gradient, steady-state values of $\mathrm{Q}$ were -1 to $+0.8 \mathrm{mV} / \mathrm{K}$, smaller than when the diopside was surrounded by silica glass in a small temperature gradient, but the time-dependent response of Q to changes in $f \mathrm{O}_{2}$ followed the same pattern found when the diopside was surrounded by silica. 
The unusual time-dependent behavior thus appears to be a property of the diopside. Following the thermoelectric power measurements, the electrical conduction ( $\sigma)$ of the crystal was almost independent of $f \mathrm{O}_{2}\left(\partial(\log \sigma) / \partial\left(\log f \mathrm{O}_{2}\right)=0.044\right.$ at $\left.1000^{\circ} \mathrm{C}\right)$.

The steady-state results suggest that (a) the dominant mobile charged defects in diopside, $900-1100^{\circ} \mathrm{C}$, are negative, (b) the temperature-dependent term for the Seebeck coefficient (in $\mathrm{mV} / \mathrm{K}$ ) is $70500 / \mathrm{K}$, and (c) the steady-state thermoelectric power is insensitive to $f_{\mathrm{o}_{2}}$. Before steady state is reached, the Seebeck coefficient senses the presence of both positively and negatively charged defects. The lack of an $f \mathrm{o}_{2}$-dependence of the steady-state $\mathrm{Q}$ and the relatively small $\partial(\log \sigma) / \partial\left(\log f_{\mathrm{O}_{2}}\right)$ are compared with $f \mathrm{o}_{2}$-independent regimes of electrical conductivity (extremes of $f \mathrm{O}_{2}$, Huebner and Voigt, 1988) and of strain rate (high $f \mathrm{O}_{2}$ and silica activity, Jaoul and Raterron, 1994) for diopside presumed to be in equilibrium with silica. The time dependent response of the Seebeck coefficient to changes in ${f \mathrm{O}_{2}}_{2}$ can be explained by reactions which create, with an increase in $f \mathrm{o}_{2}$, relatively mobile negatively charged cation vacancies and relatively immobile positive defects (ferric iron). Because there is a distinct shortterm response of the thermoelectric voltage to changes in $\mathrm{fo}_{2}$, laboratory measurements of $\mathrm{Q}$ in pyroxenes, and perhaps other materials, may not properly characterize the defects that control faster or slower transport. Further, if electrical conductivity and creep are determined by minority defects, the sign of the dominant majority charged defect(s), sensed by the Seebeck coefficient, may not be the same as the sign of the minority defects that transport electrical charge and control creep. 


\section{INTRODUCTION}

The Seebeck effect is a coupled process that relates temperature gradient (a force) and movement of charged defects (a flux). The Seebeck coefficient $(\mathrm{Q}=-\mathrm{mV} / \mathrm{K}$ ) can indicate the sign of the dominant charge-carrying defects in a material and contribute to the determination of defect concentrations. Knowledge of mobile defects is essential to an understanding of electrical transport, chemical diffusion, and creep, yet there have been few measurements of $\mathrm{Q}$ in materials of the earth's crust. Choi (cited in Tuller, 1983) measured the thermoelectric power of $\mathrm{Ba}_{0.3} \mathrm{Sr}_{0.7} \mathrm{TiO}_{3}$ (perovskite structure) and found that $\mathrm{Q}$ changed from -1.5 to $+1.2 \mathrm{mV} / \mathrm{K}$ as $f_{\mathrm{O}_{2}}$ was raised from $10^{-12}$ to $10^{-2} \mathrm{~atm}$, indicating a transition from n-type to p-type conduction. The absolute value of $\mathrm{Q}$ decreased as temperature was raised from 800 to $1100^{\circ} \mathrm{C}$. Tuller et al. (1986) investigated the electrical conductivity and thermoelectric power of $\mathrm{Mn}-\mathrm{Zn}$ ferrites (spinel structure) as a funćtion of $f_{\mathrm{O}_{2}}$ at 1000 and $1200^{\circ} \mathrm{C}$; the composition $\mathrm{Mn}_{0.9} \mathrm{Fe}_{2.1} \mathrm{O}_{4}$ (approximate) showed five different fields, each having a distinct relationship between electrical conductivity and $f_{\mathrm{o}_{2}}$. Values of $\mathrm{Q}$ were on the order of $\pm 0.1 \mathrm{mV} / \mathrm{K}$. Mason (1987) used electrical conductivity and Seebeck effect to obtain site occupancies of spinels. Knowledge of the Seebeck coefficient permitted distinction of carrier-formation from hopping energies. Schock et al. (1989) measured the thermoelectric power of San Carlos olivine, $\mathrm{Mg}_{1.83} \mathrm{Fe}_{0.17} \mathrm{SiO}_{4}$, and forsterite, $\mathrm{Mg}_{2} \mathrm{SiO}_{4}$. At $f_{2}$ $=10^{-9} \mathrm{bar}$, measured values of the Seebeck coefficient for olivine changed from +400 to -200 $\mu \mathrm{V} / \mathrm{K}$ as the temperature was raised from 1000 to $1500 \mathrm{~K}$, indicating a transition from positive to negative charge carriers. All measured values for forsterite were negative, indicating negative charge carriers, and of unusually large magnitude ( 0 to $3 \mathrm{mV} / \mathrm{K})$. The $\mathrm{fo}_{2}$ dependence of $\mathrm{Q}$ was not given. Wanamaker (1994) showed that the $f_{\mathrm{O}_{2}}$-dependence of $\mathrm{Q}$ for San Carlos olivine 
decreased with increasing temperature, $1100-1300^{\circ} \mathrm{C}$, and that measured values of $\mathrm{Q}$ were between 0.15 and $0.45 \mathrm{mV} / \mathrm{K}$. Although the rate at which electrical conductivity responded to changes in $\mathrm{fo}_{2}$ was measured, no time-dependent response of $\mathrm{Q}$ was mentioned. Hodge and Bowen $(1981,1982)$ found that, following establishment of a steady-state thermal gradient (typically $38 \mathrm{~K} / \mathrm{cm}$ ) across wüstite, the measured thermoelectric power decreased slightly $(\sim 10 \%)$ over the next $5.4 \times 10^{3} \mathrm{~s}$. They attributed this change to the formation of a concentration gradient of ionic defects in the sample that reflected the $f_{\mathrm{O}_{2}}$ gradient in the furnace. At steady-state, the thermal driving force, the opposing electrochemical potential gradient, and a bulk composition gradient due to local equilibrium between wüstite and gas having an $\mathrm{fo}_{2}$-gradient, are all balanced. Observed magnitudes of $\mathrm{Q}$ were $\leq 600 \mu \mathrm{V} / \mathrm{K}$. A casual survey of other literature on thermoelectric powers indicates that $\mathrm{Q}$ rarely exceeds $\pm 0.6 \mathrm{mV} / \mathrm{K}$. Thus the $-3 \mathrm{mV} / \mathrm{K}$ measurement of foŕsterite by Schock et al. (1989) is exceptional.

Based on electrical conductivity and sparse other physical property measurements, Huebner and Voigt (1988) noted that, between the $\mathrm{fo}_{2}$ of iron-wüstite (IW) and (IW) $\times 10^{4}$, electrical conduction $(\sigma)$, at $10-100 \mathrm{kHz}$, of Fe-poor diopside (DK7) obeys the relation $\partial(\log$ $\sigma) / \partial\left(\log f_{\mathrm{o}_{2}}\right)=\sim 0.12$ to -0.18 , close to the value $(-0.167)$ expected from the presence of oxygen vacancies, each of which creates two defect electrons. Changes in sample density and unit cell dimensions were consistent with this simple model. At extremes of $f_{2}, \sigma$ was insensitive to $\mathrm{fo}_{2}$. Huebner and Voigt (1988) further noted that the response of electrical conductivity to changes in temperature was faster than to changes in $f_{\mathrm{O}_{2}}$. When temperature and $\mathrm{fO}_{2}$ are both increased (or both decreased), a plot of conductivity versus time passes through a minimum (or maximum). Measurement of a more Fe-rich diopside (MAL) showed larger conductivity values but only a 
small $f \mathrm{o}_{2}$-dependence $\left(\sigma \propto f \mathrm{O}_{2}{ }^{-0.025}\right)$. Subsequently, Jaoul and Raterron (1994) combined measurements of the $\mathrm{fo}_{2}$-dependence of creep in diopside with the results of Huebner and Voigt (1988), proposed that conductivity and creep were insensitive to $f_{2}$ if silica precipitates were present, and developed a model in which divalent-cation $(\mathrm{Mg}, \mathrm{Fe}, \mathrm{Ca})$ vacancies, silicon vacancies, and $\mathrm{Fe}^{3+}$ were the dominant defects. They suggested that electrical conduction in the two phase region diopside $+\mathrm{O}_{2}$ (gas) was controlled by minority defects (interstitial cations and/or conduction electrons) having (theoretically) an approximately -0.167 dependence on $f \mathrm{O}_{2}$. In the three-phase region diopside + silica + gas, the $f \mathrm{O}_{2}$ dependence of the conductivity was reduced and interstitial cations were postulated to be the charge carriers. Diopsides having composition similar to DK7 could exhibit both strong and weak $f_{\mathrm{O}_{2}}$-dependence of the respective physical properties, electrical conduction and creep.

The present research explores the efficacy of a thermoelectric measurement technique for diopside, in part because the available evidence does not resolve the sign of the charge carriers in diopside, much less identify the defect species in diopside having near-endmember composition. Furthermore, a diopside crystal of suitable composition and geometry became available. Although measurement of a single diopside composition does not form as complete a study as might be desired, the heretofore undescribed kinetic effects should be brought to bear on defect models for diopside.

\section{THEORY}

Most charge-carrying defects are thermally activated. In an isothermal closed system there is no tendency for these defects to migrate and local charge balance prevails. In a thermal gradient, the concentration of thermally activated defects is greater at the hot end of the system; 
mobile defects tend to diffuse toward the cooler end until the chemical potential gradient (largely due to the concentration gradient) and the opposing electrical potential gradient (due to charge separation) balance each other. At this steady state, the sign of the voltage developed across the thermal gradient indicates the dominant sign of the charges which have migrated (or been left behind) at the ends of a sample. Measurement leads are so configured that the sign of the Seebeck (thermoelectric power) coefficient, $\mathrm{Q}=-\mathrm{dV} / \mathrm{dK}$, indicates the sign of the (mobile) charge carriers at the cool end of the sample.

Thorough reviews of the underlying theory are presented by Wimmer and Bransky (1974), Rickert (1982), Trestman-Matts, et al. (1983), and Mason (1987). One point affects the experimental design. If the measured sample is compositionally heterogeneous, as might be caused by a significant temperature gradient $\Delta \mathrm{K}$, even in a closed system, the measured thermoelectric voltage would contain a component due to the compositional gradient $\mathrm{Q}_{\text {comp }}=$ $\mathrm{Q}_{\text {total }}-\mathrm{Q}_{\text {homo }} \simeq(\mathrm{dQ} / \mathrm{dK})(\Delta \mathrm{K} / 2)$ (Trestmann-Matts, et al., 1983). In a furnace atmosphere, the compositional gradient can have two sources (Hodge and Bowen, 1982): thermal diffusion of ionic species within the sample (Soret effect) and differences in composition brought about by local equilibrium with the different $f \mathrm{O}_{2}$ values "seen" by the hot and cold ends of the sample (the $f \mathrm{O}_{2}$ of a CO- $\mathrm{CO}_{2}$ mixture is temperature dependent). Use of a small thermal gradient $\Delta \mathrm{K}$ will reduce experimental errors that might arise from ignoring sample heterogeneity.

Impedance spectroscopy permits distinction of the bulk and interfacial (sample-electrode) responses of a system such as Pt-diopside-Pt (Huebner and Dillenburg, 1995). If, under the influence of an external EMF, charge carriers cross the metal interface to enter or leave the silicate, the low frequency response will be an arc in the complex plane. If charge carriers 
accumulate at but do not cross the interface, the low frequency response approximates a straight line. The nature of the low frequency response provides a mechanism for distinguishing the presence of electronic charge carriers (electrons or electron-holes), which can cross the interface, and mobile ions, which cannot enter the Pt metal electrodes.

\section{EXPERIMENTAL CONFIGURATION}

This work reports on thermoelectric powers of three sample assemblies: diopside + silica glass, silica glass alone, and diopside alone. Figure 1 is a schematic diagram of the experimental configuration. The voltage $\mathrm{V}_{\mathrm{m}}$ measured between leads $\mathrm{A}$ and $\mathrm{D}$ consists of several components. If the voltmeter makes no significant contribution to the measured voltage, $\mathrm{V}_{\mathrm{m}} \approx \mathrm{V}_{1}+\ldots . .+\mathrm{V}_{6}$. $V_{1}$ and $V_{2}$, the absolute thermoelectric powers of Pt induced by the thermal gradient $T_{\text {cool }}$ to $T_{\text {ice }}$, are equal but opposite in sign. $\mathrm{V}_{3}$ is the absolute thermoelectric power of the portion of the hot Pt lead that lies in the thermal gradient $T_{\text {hot }}$ to $T_{\text {cool }}$; this value is about $-20 \mu \mathrm{V} / \mathrm{K}$ (Nyström, 1957; Cusack and Kendall, 1958; Bauerle et al., 1961). When the temperature gradient is $<5 \mathrm{~K}, \mathrm{~V}_{3}$ $<<\left|V_{\mathrm{m}}\right|$, which we observed to be 5 to $35 \mathrm{mV}$ for diopside. Were this correction to have been made, it would reduce the magnitude of the observed thermoelectric power, but by an insignificant amount. During measurement of silica glass, the temperature gradient was much greater and the Seebeck coefficient less than in the case of the diopside, so $\mathrm{V}_{3}$ could be several \% of $\mathrm{V}_{\mathrm{m}}$. Voltages $\mathrm{V}_{4}$ and $\mathrm{V}_{6}$ are induced by the similar junctions, Pt-diopside and diopside-Pt. Although these voltages are unknown, they are opposite in sign and, because our experimental temperature gradient is small, should have almost equal magnitudes so that $\mathrm{V}_{4}+\mathrm{V}_{6} \simeq 0$.

Therefore, $\mathrm{Q} \cong-\mathrm{mV} / \mathrm{K} \approx \mathrm{V}_{\mathrm{m}}=\mathrm{V}_{5}$, referred to the mean temperature between $\mathrm{T}_{\mathrm{h}}$ and $\mathrm{T}_{\mathrm{c}}$. The diopside (Rotkopschart, Zillertal, Austria) was purchased from Wards Natural 
Science Establishment. Unit cell dimensions, measured with an X-ray powder diffractometer and using $\mathrm{BaF}_{2}$ internal standard, are $a=9.7549(6) \AA, b=8.9295(7) \AA ̊ ., c=5.2508(7) \AA$, and $\beta=105.79(1)^{\circ}$, indistinguishable from those of the endmember $\mathrm{CaMgSi}_{2} \mathrm{O}_{6}$ composition. The crystal is $24.4 \times 4.95 \times 6.85 \mathrm{~mm}$, has its long axis parallel to $c$, and is twinned parallel to $c$, resulting in a satiny lustre. The electron microprobe analysis contained 0.003 excess cations per six-oxygen formula unit and did not distinguish ferrous and ferric iron. Although one cannot be certain that $\mathrm{Fe}^{3+}$ cations were initially present, we recalculated the electron microprobe chemical analysis by converting $0.0091 \mathrm{Fe}^{2+}$ cations to $\mathrm{Fe}^{3+}$ to achieve the ideal cation/anion ratio of $4: 6$, thereby raising the summation from 100.37 to 100.40 weight- $\%$. (Cation vacancies would be associated with higher ferric concentrations and higher oxide weight-percent summations.) If $\mathrm{Fe}^{3+}$ is present, it enters the ideal diopside-hedenbergite solid solution, $\mathrm{Ca}\left(\mathrm{Mg}, \mathrm{Fe}^{2+}, \mathrm{Fe}^{3+}\right) \mathrm{Si}_{2} \mathrm{O}_{6}$, through substitutions such as $\left(\mathrm{Fe}^{3+}\right)^{\mathrm{VI}}=\left(\mathrm{Al}^{3+}\right)^{\mathrm{IV}}$ and $\left(\mathrm{Fe}^{3+}\right)^{\mathrm{VI}}=\left(\mathrm{Fe}^{3+}\right)^{\mathrm{IV}}$. (Alternatively, the $\mathrm{SiO}_{2}$ could have been increased by $0.25 \%$, less than the estimated analytical uncertainty, \pm 1.0 relative $\%$, but some Si would then be octahedrally coordinated and the summation would have risen to 100.62 weight-\%). It is probable that the $\mathrm{P}_{2} \mathrm{O}_{5}$ and $\mathrm{ZnO}$ are artifacts of the background correction; deletion of these elements decreases the total to $100.31 \%$ and the number of $\mathrm{Fe}^{3+}$ cations per formula unit to 0.0078 ).

The crystal was prepared for the furnace assembly by cutting grooves perpendicular to $c$ and $17.6 \mathrm{~mm}$ apart. Each groove received two turns of $0.4 \mathrm{~mm}$ diameter $\mathrm{Pt}$ wire. The long end of each Pt wire led outside the furnace and the bitter (short) end of each lead was welded to a long length of $\mathrm{Pt}_{90} \mathrm{Rh}_{10}$ lead to form a thermocouple adjacent to each end of the sample. Mechanical support was provided by sliding the sample assembly into a pure silica-glass sleeve 
(Thermal American Fused Quartz Company vitreous silica; Li, K, Na total 4.2 ppm in a typical analysis), $27.05 \mathrm{~mm}$ long and having $8.05 \mathrm{~mm}$ inner diameter. Four wire leads were brought out through a $0.70 \mathrm{~mm}$-wide vertical slit cut in the sleeve. The turns of Pt wire prevented the diopside from making physical contact with the silica glass. If the silica tube could communicate with the nearby sample, the silica activity should be raised or maintained near unity.

The silica sleeve - diopside crystal assembly was positioned vertically in the furnace muffle tube (McDanel 998 alumina) and centered beneath the hot spot, so that the upper end was hotter (by $1.5-4.9^{\circ} \mathrm{C}$ ) than the lower end. The four metal leads passed through the bottom of the muffle tube and led directly to(individually isolated copper junctions in an ice bath (fig. 1). The copper leads made contact with the measurement circuit (described below). Except during an actual EMF measurement, the room-temperature ends (A..D) of the copper leads were isolated from the measurement apparatus. Furnace $\mathrm{fO}_{2}$ was controlled by mixtures of $\mathrm{CO}$ and $\mathrm{CO}_{2}$ gases, metered electronically using solid state valves, and measured with a calcia-doped zirconia cell (Huebner, 1987). The $f \mathrm{o}_{2}$ about the sample began to change about 4 minutes after the gas mixture was changed and required about 30 minutes to reach a new steady-state $f \mathrm{O}_{2}$. Following thermoelectric power measurements of diopside + silica glass sleeve, the outer surface of the silica glass tube had a uniform thin white (devitrified) skin but much of the inner surface was still glassy, suggesting that whatever caused the devitrification (trace of alkali?) came from the furnace environment, not from the diopside. The diopside crystal was intact, unchanged in color, and water-clear, not satiny. An unusual amount of a mixture of magnetite, hematite, and poorly crystallized carbon coated ceramics that had been in the lower, cooler end of the muffle tube, but did not reach the sample or hot spot. The source of the iron might be $\mathrm{Fe}(\mathrm{CO})_{6}$ impurity in the 
steel CO tank used during measurment of diopside + silica, and precipitation of carbon as CO$\mathrm{CO}_{2}$ mixtures are heated is a well-known problem. It was the first series of measurements made in this muffle tube without exposed Pt tubes or Pd-black paint in the lower (cooler) part of the assembly. Perhaps the absence of these potentially catalytic surfaces explains the large quantity of the carbon in the precipitate. Subsequent measurements (silica sleeve, diopside) used a new $\mathrm{CO}$ tank and resulted in carbon but not iron oxide precipitates. The silica sleeve emerged almost unaltered.

The DC source resistance of the diopside was expected to be large from the results of Huebner and Voigt (1988) and was initially found to be $38 \mathrm{M} \Omega\left(1000^{\circ} \mathrm{C}\right.$ and log-bar $\left.f \mathrm{o}_{2}=-11.0\right)$ using a digital electrometer (Keithley 616). Preliminary thermopower measurements indicated that the diopside crystal would generate $\leq 20 \mathrm{mV}$. Measurement of a small DC EMF generated by a source having a large internal resistance can be subject to two kinds of systematic errors that would not be significant if the source had a low internal resistance: voltage drop by a factor (source resistance)/(voltmeter internal resistance) and $E=I R$ error where $(I=$ current at the high terminal of the voltmeter and $\mathrm{R}=$ source resistance). In addition, AC "noise" from the laboratory environment (including the furnace) can randomly perturb fast DC measurements. Measurements were made using a Guildline \#9576 digital multimeter (DMM, equivalent to a Solartron \#7065) because it had a long integration time (1.06 s) and the ability to average repetitive readings - commonly 100-1000 readings. Specifications for this unit indicate an input resistance $>10^{11} \Omega$ and a high-terminal (offset) current $< \pm 20 \mathrm{pA}$ leading, ideally, to a voltage drop $\leq 0.04 \%$ and an $E=\mathbb{R}$ error $\leq \pm 0.8 \mathrm{mV}$. Four observations suggest that these expectations were met. (1) No voltage drop was observed with the electrometer until its input resistance was 
decreased to $\leq 10^{10} \Omega$; thus, a DMM with $>10^{11} \Omega$ input resistance is appropriate for the measurement. (2) The magnitude of the DMM measurements were as great, and were more stable, than electrometer measurements made with $10^{14} \Omega$ input resistance. (3) When the DMM was accidentally and momentarily switched to measure ohms, the charge applied to and stored by the diopside (or separately, the silica glass) took many minutes to several hours to dissipate (observed as measured voltage changing from hundreds of $\mathrm{mV}$ to normal value), indicating that little current passed through the DMM or leaked between the leads. (4) Changing the polarity of the DMM leads (interchanging the hot and cold leads) did not significantly change the measurement, indicating insignificant offset current developed within the DMM.

The critical relationship between direction of electron flow through the DMM and polarity of the reported measurements was confirmed using an Eppley (Weston-type) cell. In the circuit external to the cell, electrons flow from the negative terminal, at which $\mathrm{Cd}^{0}$ is oxidized to $\mathrm{Cd}^{2+}$, to the positive terminal, at which $\mathrm{Hg}^{2+}$ is reduced to $\mathrm{Hg}^{0}$. When the low (black) lead of the DMM is connected to the negative terminal of the Eppley cell, electrons flow through the DMM from the low to the high leads, and the measured voltage is positive. A flashlight battery gave a similar result. Thus, when the black DMM lead is connected to the cool (lower) end of a sample, a positive DMM measurement corresponds to the accumulation of negatively charged carriers at the cool end of the sample.

For equilibrium or near-steady-state measurements, the pattern was to measure the EMF of the upper and lower thermocouples, measure the thermoelectric voltage of the sample in both polarities, then measure the thermocouples in reverse polarity. Many voltage readings were averaged to provide a DMM measurement. When the temperature gradient was small, the 
absolute values of the pairs of thermocouple EMF readings were averaged and converted to a temperature gradient using $\mathrm{d}(\mathrm{EMF}) / \mathrm{d}\left({ }^{\circ} \mathrm{C}\right) \sim 11.2,11.5$, and $11.8 \mu \mathrm{V} /{ }^{\circ} \mathrm{C}$ at 1173,1273 , and 1371 K, respectively (Bedford et al., 1972). For larger temperature gradients, thermocouple EMF readings were converted directly to temperatures using the tables of Burns et al. (1993). The absolute values of the two measurements of thermoelectric EMF (different polarities) across the copper leads that were soldered to the Pt leads were within $10 \%\left(900^{\circ} \mathrm{C}\right)$ to $2 \%\left(1000^{\circ} \mathrm{C}\right)$ of each other. The pairs were averaged, then divided by the temperature gradient, to yield $\mathrm{Q}=$ $-\mathrm{mV} / \mathrm{K}$. During non-steady-state measurements, when the change in thermoelectric voltage was rapid relative to the time necessary to measure the thermocouples or to average hundreds of readings across a sample, fewer voltage readings were averaged and thermocouple measurements were infrequent.

\section{Experimental Results}

\section{Diopside + Silica Glass}

The assembly was measured in a small temperature gradient $(1.5-4.9 \mathrm{~K})$. Measured thermoelectric power was converted to $\mathrm{Q}$ using contemporaneous thermal gradients that may differ from the long-term average values reported in Table 2. Numerous steady-state measurements revealed positive DMM measurements exclusively, indicating that the dominant charge carriers are negative. Measured thermoelectric powers so greatly exceed that developed by the Pt lead parallel to the silica glass sleeve $(\leq 0.1 \mathrm{mV})$ that no correction was made. Magnitudes of $\mathrm{Q}$ were unexpectedly large; many determinations of steady-state $\mathrm{Q}$ were more negative than $-5 \mathrm{mV} / \mathrm{K}$.

Isothermal changes in the proportions of $\mathrm{CO}$ to $\mathrm{CO}_{2}$ supplied to the furnace stimulated 
several responses (Table 2; fig. 2). (i) The $f_{\mathrm{O}_{2}}$, monitored as the EMF of the oxygen concentration cell, rose or fell to new steady state values relatively quickly; most of the $f \mathrm{o}_{2}$ change was accomplished in $<1000 \mathrm{~s}$. (ii) $\mathrm{Q}$ began to rise or fall as soon as the furnace $\mathrm{fO}_{2}$ began to change and reached a maximum or minimum at $800-6000 \mathrm{~s}$, after the $\mathrm{fo}_{2}$ reached steady state. (iii) Whenever $\mathrm{fO}_{2}$ was increased, Q decreased, and vice versa. This effect was so pronounced that, when $\mathrm{fO}_{2}$ was decreased, $\mathrm{Q}$ become positive for a short time, indicating a temporary change to dominantly positive charge carriers. (iv) Q slowly returned to close to its original value, changing sign again if necessary. In some cases, more than $1.5 \times 10^{6} \mathrm{~s}$ were necessary for the sample to reach a new steady state.

Steady-state values of Q, from Table 2, are plotted against temperature in Figure 3. Three kinds of measurements are distinguished: $Q$ following an increase in $\mathrm{fo}_{2}, \mathrm{Q}$ following a decrease in $\mathrm{fO}_{2}$, and $\mathrm{Q}$ values that are not associated with a change in oxygen-fugacity (most were recorded before the short-term response to changes in $\mathrm{fo}_{2}$ was recognized). The data suggest a trend whereby the absolute magnitude of Q increases with temperature; this is reasonable because $\mathrm{V}=\mathrm{qd} / \epsilon \mathrm{A}$ : increasing the population of mobile charge carriers should lead to greater charge imbalance (q, in coulombs) while the sample length (d), cross-sectional area (A), and absolute permittivity $(\epsilon)$ of the diopside remain essentially constant. Values of isothermal steady-state Q, following increase and decrease in $\mathrm{fO}_{2}$, cluster tightly. Considering the three to four orders-ofmagnitude change in $\mathrm{fO}_{2}$, the steady-state Seebeck coefficient appears insensitive to oxygen fugacity. At 900 and $1000^{\circ} \mathrm{C}, \mathrm{Q}$ at low $\mathrm{fo}_{2}$ (following a decrease in $f_{\mathrm{O}_{2}}$ ) is less negative than $\mathrm{Q}$ at high $f_{2}$, but at $1100^{\circ} \mathrm{C}$ the situation is reversed. This exchange of position may not be real; even small variations in the short-term thermal gradient can introduce significant errors in the 
calculation of $\mathrm{Q}$ when $\Delta \mathrm{T}$ is small $\left(1.6-2.0^{\circ} \mathrm{C}\right.$ at $\left.1100^{\circ} \mathrm{C}\right)$. Overall, it is probably correct to conclude that the steady-state Seebeck coefficient of diopside shows distinct temperature dependence $\left(\mathrm{Q}_{(\mathrm{mV} / \mathrm{K})}=-61.7( \pm 1.7 \mathrm{mV} / \mathrm{K})+70500( \pm 9800 \mathrm{mV}) / \mathrm{K}\right.$ with $\left.\mathrm{R}^{2}=83 \%\right)$ but is insensitive to $\mathrm{fO}_{2}$.

\section{Silica Glass}

A silica glass tube, $0.049 \mathrm{~m}$ long, cut from the same stock and adjacent to the sleeve used to support the diopside tube, was measured in a $49-62^{\circ} \mathrm{C}$ gradient. Values of the thermoelectric power were on the order of $-20 \mathrm{mV}$ and so greatly exceed the thermoelectric power developed by the Pt lead parallel to the silica glass sleeve (on the order of $-1 \mathrm{mV}$ ) that no correction was made. Following runup to $1000^{\circ} \mathrm{C}$, all but two values of $\mathrm{Q}$ were in the range +0.17 to $+0.83 \mathrm{mV} / \mathrm{K}$ (Table 3). In six of nine cases, an increase (decrease) in $\mathrm{fO}_{2}$ brought about an increase (decrease) in $\mathrm{Q}$, but these short-term excursions of $\mathrm{Q}$ were much smaller than when diopside was present. The change in long-term $\mathrm{Q}\left(\mathrm{Q}_{\text {final }}-\mathrm{Q}_{\text {initial }}\right)$ did not consistently relate to changes in $f \mathrm{o}_{2}$. The dominant charge carrier is positive over the range of temperature and oxygen fugacity explored. Further, in the absence of diopside, there is no significant response of $Q$ to changes in $f \mathrm{O}_{2}$. Neither the silica glass, furnace ceramics, nor the DMM and its leads are directly or solely responsible for either the large values of $\mathrm{Q}$ measured for diopside or the pronounced changes in $\mathrm{Q}$ in response to changes in $\mathrm{fo}_{2}$.

\section{Diopside}

The same diopside crystal without the surrounding silica glass sleeve was finally measured in a larger thermal gradient (Table 4) to confirm that Q still had a short-term response to changes in $\mathrm{fO}_{2}$. As in the case of diopside surrounded by silica glass, when $\mathrm{fO}_{2}$ was increased, 
Q momentarily decreased, and vice-versa. Thus the silica glass sleeve is not necessary for this unusual short-term behavior. But in contrast to the diopside + silica assembly, values of Q measured at steady state (constant $f \mathrm{o}_{2}$ ) were all less than $1 \mathrm{mV} / \mathrm{K}$, values that are smaller than when the crystal was first measured with surrounding silica. Both positive and negative values were observed, as if there was a near balance between positive and negative charge carriers that is influenced by factors not yet understood. Because the steady state $Q$ is so small, in each of the three cases in which $\mathrm{fO}_{2}$ was lowered, $\mathrm{Q}$ became distinctly positive, indicating a momentary change in the sign of the dominant charge carrier, as seen with the diopside + silica assembly.

Impedance spectra of the diopside crystal taken at $1000^{\circ} \mathrm{C}$ and $\log f \mathrm{o}_{2}$ (in bars) values of 8.68 and -12.78 are shown in figure 4. Following substantial nulling correction (which assumed that the open circuit response is parallel to the diopside sample; see Christensen et al., 1994, and Hsieh et al., 1996), resistances for the large (bulk) arc are 68.79 and $45.55 \mathrm{M} \Omega, \partial(\log$ $1 / \mathrm{R}) / \partial\left(\log f \mathrm{o}_{2}\right)=0.044$, and the capacitance is $6 \mathrm{pF}$. (For the complex non-linear least-squares fitting of the spectra, see Huebner and Dillenburg, 1995.) Resistance decreases with $f_{2}$, as found by Huebner and Voigt (1988), but the rate of decrease is smaller than found for diopside DK7 which has similar composition. The incomplete small arc suggests that some charge carriers cross the diopside-Pt metal interface with relatively small resistance. Were none of the carriers able to cross the interface, the trend of the response would rise steeply as frequency decreased (see figure 3 of Huebner and Dillenburg, 1995). Possible charge-carrying species are electrons or electron holes (which would pass directly between silicate and metal) and oxygen defects (if they participated in an equilibrium with $\mathrm{O}_{2}$ in the furnace gas and electrons in the metal). Cation vacancies and interstitials cannot cross the interface into the platinum electrodes. 
Because the Rotkopschart diopside was long and the electrode area was small, the impedance analyzer operated under less than ideal conditions. Impedance spectra measured from thin plates of DK7 diopside, which has composition similar to that of the Rotkopschart diopside, confirm the observations (see Huebner and Dillenburg, 1995). The low frequency arc is completely closed and the bulk response lies above $10 \mathrm{~Hz}$.

Following quenching, optical microscopy of a fragment of the crystal revealed inclusions aligned in healed fractures or twin planes. Siliceous precipitates, which might appear as micronsized ellipsoidal bodies of glass (quenched melt) dispersed throughout the diopside, were not observed.

\section{Effect of Imposed EMF}

Perturbations in the measured thermoelectric voltages were accidentally caused by shorting the leads $\AA$ and $D$ (fig. 1), touching the leads with fingers, and causing the DMM to measure resistance by imposing a DC voltage across the samples (see Tables 3 and 4). After the stimulus was removed, maximum observed perturbations were $-300 \mathrm{mV}$ for the diopside; these excursions of measured thermoelectric voltage developed quickly (too rapidly to measure) and relaxed completely within $6 \times 10^{3} \mathrm{~s}$, suggesting that their cause is unrelated to the response due to

changes in $\mathrm{fo}_{2}$ described above. When charge was injected into the silica-glass sample assembly, it dissapated more slowly (the magnitude of the DMM reading fells from $800-1000 \mathrm{mV}$ to normal values of $14-20 \mathrm{mV}$ over a period of several hours). This observation indicates the absence of a conductive pathway through the silica, gas phase, or insulating ceramics, or between the metal leads. 


\section{Discussion}

The Seebeck coefficient for diopside is larger than that of other compounds, for which the absolute magnitudes of the coefficients are commonly $<1 \mathrm{mV} / \mathrm{K}$, always less than $3 \mathrm{mV} / \mathrm{K}$. At $900-1100{ }^{\circ} \mathrm{C}$, the magnitude of the Seebeck coefficient increases with temperature and is consistent with an increase in thermally activated charge carriers if we assume that the ratio of positive and negative charges remains approximately constant (for instance, Frenkel defects). The dominant charge carriers are negative. Impedance spectroscopy suggests that electronic defects (or oxygen interstitials) are important at the diopside-electrode interface. But the presence of mobile electrons or oxygen interstitials explains neither the short-term response of Q to changes in ambient $f_{2}$ nor the observed difference in steady-state $\mathrm{Q}$ when diopside was measured first with, then without, the silica glass sleeve. The observation that steady-state Q was insensitive to $\mathrm{fo}_{2}$ suggests that (1) the experimental $f_{\mathrm{O}_{2}}$ was beyond some limiting value for the process (see Huebner and Voigt, 1988) or (2) the diopside was in equilibria with silica either because of a siliceous initial composition or exsolution of silica during the measurements (see Jaoul and Ratterson, 1994).

The maximum and minimum in $\mathrm{Q}$, measured following a decrease or increase in $f \mathrm{o}_{2}$, was not expected. This behavior, which indicates significant changes in the relative concentrations of positive and negative charge carriers with time, lacks precedence. Huebner and Voigt (1988) studied diopside of similar composition and found that, in the few hours following an isothermal change in $\mathrm{fo}_{2}$, the electrical conductivity changed monotonically, more quickly than expected from an oxygen diffusion mechanism, but consistent with their finding that $\log \sigma$ was proportional to $\left(\log f_{2}\right)^{-0.15}$. Specifically, they did not observe a maximum or minimum in $\sigma$ at 
constant temperature. Because conductivity depends on the nature, mobilities, and concentrations of charged defects, it is puzzling that the electrical conductivity measurements did not reveal the complex response found when measuring $\mathrm{Q}$.

Maxima and minima are difficult to explain. The most similar observations are those of Hodge and Bowen $(1981,1982)$, who found that $\mathrm{Q}$ decayed to a lower value during the $5400 \mathrm{~s}$ (typical) following imposition of a $100-200{ }^{\circ} \mathrm{C}$ temperature gradient on a previously isothermal sample. Their explanation was that the temperature gradient caused an oxygen fugacity gradient in the $\mathrm{CO}-\mathrm{CO}_{2}$ furnace gas mixture, which in turn caused a composition gradient across their 50

mm sample. (Wüstite, $\mathrm{Fe}^{2+}{ }_{1-3 \mathrm{X}} \mathrm{Fe}^{3+}{ }_{2 \mathrm{X}} \mathrm{D}_{\mathrm{X}} \mathrm{O}$, is noted for its wide range of nonstoichiometry.) Thus, the change in $\mathrm{Q}$ reflected ionic diffusion in response to this compositional gradient. The relaxation time observed by Hodge and Bowen is similar to the time needed for the thermoelectric voltage of diopside to reach its maximum or minimum. In contrast, diopside is a mineral that has only a small range of stoichiometry (diopside composition at 1 bar) and the $f \mathrm{O}_{2}$ gradient was minimized by using a $2-5^{\circ} \mathrm{C}$ gradient over $18 \mathrm{~mm}$ of sample, yet a more complex response was observed. (Subsequent measurements of the electrical conductivities of 12-15 mmlong diabase cylinders in the same furnace did not revealed time-dependent behavior like that found when measuring $Q$ ).

\section{Defect Reactions}

The temporal change of the sign of $\mathrm{Q}$ indicates that the dominant charge carrier can change from negative to positive; thus, more than one kind of mobile charge-carrying defect must be present in diopside. The short-term maximum (minimum) followed by slow relaxation 
suggests the operation of two distinct rate constants. The $f_{\mathrm{O}_{2}}$-independence of steady-state $\mathrm{Q}$ and the small variation of $\sigma$ with $f_{2}$ suggest that, at least during the final measurements, the diopside might be in equilibrium (buffered) with silica or olivine, whether or not the silica glass sleeve is present. Consideration of two rate constants among species in a two-phase (homogenous solid) system and two distinct reactions in a three-phase (heterogeneous solid) system is a possible approach.

Some possible point defects and their $\mathrm{fO}_{2}$-dependence are listed in Table 5. Calcium is assumed to be inert (as $\mathrm{Ca}_{\mathrm{Me}}{ }^{\mathrm{x}}$ ) or to behave as magnesium. Associated defects are not considered. The distinction between energetically favorable and unfavorable defects is qualitative and based on defect species in olivine, knowledge that chains of linked $\mathrm{SiO}_{4}$ tetrahedra in pyroxenes are very stable, and the fact that, at high pressure and temperature, a large fraction of octahedral vacancies are stable (and metastably quenchable) for some aluminum-rich compositions (Ca-Eskola component; see review by Gasparik and Lindsley, 1980). The Rotkopschart diopside used in this study is Al-poor and, at the time of chemical analysis, stoichiometric or nearly so.

The most likely source of a temperature-dependent, $f \mathrm{O}_{2}$-independent population of negatively charged defects are Frenkel reactions such as

$$
\begin{aligned}
& \mathrm{O}_{\mathrm{o}}^{\mathrm{x}} \rightleftharpoons \mathrm{V}_{\mathrm{O}}^{\ddot{*}}+\mathrm{O}_{\mathrm{I}}^{\ddot{*}} \\
& \mathrm{Si}_{\mathrm{Si}}{ }^{\mathrm{x}} \Rightarrow \mathrm{V}_{\mathrm{Si}}{ }^{\cdots \cdots}+\mathrm{Si}_{\mathrm{I}} \\
& \mathrm{Me}_{\mathrm{Me}}^{\mathrm{X}} \neq \mathrm{V}_{\mathrm{me}}{ }^{\prime \prime}+\mathrm{Me}_{\mathrm{I}}
\end{aligned}
$$

and an electronic jump from a ferrous cation to the conduction band,

$$
\mathrm{Fe}_{\mathrm{Me}}{ }^{\mathrm{x}} \neq \mathrm{Fe}_{\mathrm{Me}}+\mathrm{e}^{\prime}
$$


Based on the assumption that oxygen interstitials (negative) and silicon vacancies (also negative) are energetically unfavorable, reactions $1 \mathrm{a}$ and $1 \mathrm{~b}$ are unlikely to have an important responsibility for the observed negative steady-state values of Q. Reaction $1 \mathrm{c}$ is a possibility if the octahedral cation vacancies (negatively charged) are more mobile that the corresponding interstitials (positive). Reaction Id produces highly mobile electrons and explains the sign of the steadystate Seebeck coefficient. This is the reaction proposed by Huebner and Voigt (1988) to explain the electrical conductivity of MAL, a ferrous diopside that showed little $f_{\mathrm{O}_{2}}$ dependence.

When $\mathrm{O}_{2}$ is suddenly increased, the concentration of mobile negative charge carriers soon increases (or mobile positive carriers are consumed) so that the Seebeck coefficient becomes more negative. An equation for the two-phase region diopside + gas considers cation vacancies and electron holes to be the majority defects (as distinct from the mobile charge carriers), should respond rapidly to changes in $f_{2}$, and has been considered by Huebner and Voigt (1988) and by Jaol and Ratteron (1994, their equation 4):

$$
6 \mathrm{Fe}_{\mathrm{Me}}^{\mathrm{x}}+6 \mathrm{Si}_{\mathrm{Si}}^{\mathrm{x}}+18 \mathrm{O}_{\mathrm{O}}^{\mathrm{x}}+3 / 2 \mathrm{O}_{2}=6 \mathrm{Si}_{\mathrm{Si}}^{\mathrm{x}}+21 \mathrm{O}_{\mathrm{O}}^{\mathrm{x}}+\mathrm{V}_{\mathrm{me}}{ }^{\prime \prime}+\mathrm{V}_{\mathrm{Si}}^{\prime \cdots}+6 \mathrm{Fe}_{\mathrm{Me}}
$$

where $\mathrm{Me}=\mathrm{Mg}, \mathrm{Fe}, \mathrm{Ca}$. This reaction permits the cation/oxygen ratio to vary but retains $\mathrm{Me}: \mathrm{Si}=1: 1$ stoichiometry: equal numbers of negatively-charged tetrahedral and octahedral vacancies are created or destroyed. Charge balance is maintained by creating positively charged electron holes, here associated with $\mathrm{Fe}_{\mathrm{Me}}{ }^{\mathrm{x}}$ (to make ferric iron). If silicon vacancies are sufficiently energetically favorable to be a majority defect and the vacancies are more mobile than $\mathrm{Fe}_{\mathrm{Me}}$ (or the holes associated with $\mathrm{Fe}_{\mathrm{Me}}^{\mathrm{x}}$ ), reaction 2 could explain the response of the Seebeck coefficient to changes in $f_{\mathrm{O}_{2}}$. When $f_{\mathrm{O}_{2}}$ is increased, some mobile negatively charged vacancies migrate to the cool end of the diopside, causing a local charge imbalance, and the 
Seebeck coefficient becomes more negative (fig. 5). Subsequently some of the slower $\mathrm{Fe}_{\mathrm{Me}}$ (or h) Migrate to the cool end, tending to restore local change balance and causing the Seebeck coefficient to become less negative. When $f_{\mathrm{O}_{2}}$ is decreased, more defects must be consumed at the hot end of the sample than at the cold end. Because the negatively charged vacancies migrate more quickly that the positively charged ferric iron sites, the Seebeck coefficient passes through a temporary maximum value which may be positive. However, this simple model does not account for other kinds of transport measurements. The defect concentrations in reaction 2 vary with $f_{\mathrm{O}_{2}}{ }^{+3 / 2}$, which is not observed in any electrical conductivity or creep measurements, whether or not silica is present. Jaoul and Raterron (1994) avoided this dilemma by allowing Me:Si to depart from ideal 1:1 stoichiometry (to vary the $f_{\mathrm{O}_{2}}$-dependence). They assumed that the deviation from the ideal oxygen to cation ratio $(\mathrm{O} /(\mathrm{Si}+\mathrm{Me})=3 / 2)$ was much greater than the deviation from the ideal silicon to total cation ratio $(\mathrm{Si} /(\mathrm{Si}+\mathrm{Me})=1 / 2)$. From Equation (2) and the new $f_{2}$-dependence,

$$
\left[\mathrm{V}_{\mathrm{me}}{ }^{\prime \prime}\right] \propto\left[\mathrm{V}_{\mathrm{Si}}^{\cdots \cdots}\right] \propto 6\left[\mathrm{Fe}_{\mathrm{Me}}\right] \propto f \mathrm{o}_{2}^{3 / 16}
$$

then coupled equilibria ( $1 \mathrm{~b}$-d) with (3) to obtain minority defects with $f_{\mathrm{O}_{2}}$-dependence

$$
\left[\mathrm{Me}_{1}^{*}\right] \propto\left[\mathrm{Si}_{1}{ }^{\cdots}\right] \propto\left[\mathrm{e}^{\prime}\right] \propto f \mathrm{o}_{2}{ }^{-3 / 16}
$$

This $f \mathrm{O}_{2}$-dependence is consistent with experimental measurements of electrical conductivity and creep when the diopside is not saturated with silica. This model raises the interesting possibility that the observed time-dependent response of the Seebeck coefficient measures the sign of the majority charge defects but not the defects responsible for electrical conductivity measured at, say, $1 \mathrm{kHz}$. For instance, at modest frequency, conductivity could be caused by a small number 
of mobile electrons that move more quickly than cation interstitials, whereas a Seebeck measurement, a "DC" technique, would be sensitive to the presence of vacancies and interstitials that migrate slowly and accumulate in the diopside adjacent to the blocking electrodes. A negative Seebeck coefficient could be consistent with electrical transport by charged [ $\mathrm{Me}_{\mathrm{i}}$ ] and $\left[\mathrm{Si}_{1}{ }_{1}{ }^{\prime}\right]$ if the concentrations of these minority carriers are small compared with the concentrations of negatively charged majority vacancies. Thus, the negative Seebeck coefficient need not indicate conduction by the electrons in equation 4 . However, it is not yet clear that electrical conductivity and creep are controlled by small concentrations of the defects listed in equation 4 yet insensitive to the mobile majority defects in reaction 3. Further, this model (equation 2) assumes that $\mathrm{V}_{\mathrm{Si}}^{\cdots \cdots}$ is an energetically favorable defect species, which is unlikely.

Another approach is to consider how achievement of electroneutrality changes with various silica activities over a wide range in $f_{2}$. A good model is that for olivine by Stocker (1978c) and Stocker and Smyth (1978). In the case of pyroxene, the slopes of the reactions would change (because the ratios of oxygen, tetrahedral, and octahedral sites are different) but not change sign. In all cases, electrons or $\mathrm{V}_{\mathrm{Si}}^{\ldots \cdots}$ are dominant at low $\mathrm{fo}_{2}$. Because electrons are highly mobile, decreasing $f_{\mathrm{O}_{2}}$ would cause the Seebeck coefficient to become more negative, which was not observed. Again, it is unlikely that $\mathrm{V}_{\mathrm{si}}^{\prime a \cdot}$ is an energetically favorable species. This approach, allowing the charge neutrality condition to change with $f \mathrm{o}_{2}$, does not appear successful at low values of $f \mathrm{O}_{2}$.

Following the report by Ingrin et al. (1991) that diopside displaying $f_{\mathrm{o}_{2}}$-independent creep contained silica precipitates, Jaoul and Ratteron (1994, their eqn. 7) proposed the following reaction involving diopside + silica + gas: 


$$
\begin{gathered}
4 \mathrm{Fe}_{\mathrm{Me}}{ }^{\mathrm{x}}+2 \mathrm{Me}_{\mathrm{Me}}{ }^{\mathrm{x}}+6 \mathrm{Si}_{\mathrm{Si}}^{\mathrm{x}}+18 \mathrm{O}_{\mathrm{O}}^{\mathrm{x}}+2 \mathrm{SiO}_{2}+\mathrm{O}_{2}(\mathrm{~g})= \\
2 \mathrm{Me}_{\mathrm{Me}}{ }^{\mathrm{x}}+8 \mathrm{Si}_{\mathrm{Si}}^{\mathrm{x}}+24 \mathrm{O}_{\mathrm{O}}^{\mathrm{x}}+2 \mathrm{~V}_{\mathrm{Me}}{ }^{\prime \prime}+4 \mathrm{Fe}_{\mathrm{Me}}
\end{gathered}
$$

Because reaction (5) involves equilibration between two solids (or a solid and a melt) and gas, it is plausible that it would proceed more slowly than reaction (2), which involves only one solid and gas. Indeed, Jaoul and Ratteron (1994, p. 9436) alluded to this possibility. They showed that under appropriate conditions, this reaction is relatively insensitive to $\mathrm{fo}_{2}$. Huebner and Voigt (1988) and Jaoul and Raterron (1994) also found ranges of $\mathrm{fo}_{2}$ and different diopside compositions that showed little or no $\mathrm{fo}_{2}$-dependent electrical conduction or creep. The last measurement on the Rotkopschart diopside showed that its electrical conductivity was insensitive to $\mathrm{fo}_{2}$, as if silica were present, although it is possible that the $\mathrm{fO}_{2}$-dependence of the conductivity during the first series of measurements could have been much greater. If reaction 5 is the controlling reaction, an increase in $\mathrm{fo}_{2}$ would consume silica precipitates to form magnesium vacancies and electron holes. If, following the reasoning of reaction 4 , the vacancies were more mobile than holes associated with $\mathrm{Fe}_{\mathrm{Me}}{ }^{\mathrm{x}}$, an increase in $f \mathrm{O}_{2}$ would temporarily cause the Seebeck coefficient to become more negative. Reaction 5 is subject to minority carrier reasoning similar to that presented for reaction 2 and has the advantage that $\mathrm{V}_{\mathrm{Si}}^{\prime \cdots \prime}$, presumed energetically unfavorable, is not a majority defect.

Reaction 5 does not make use of the hypothesis that the relaxation of the Seebeck coefficient is due to the presumed slow rate at which silica precipitates from, or are consumed by, diopside. Reactions which involve silica and consume defects formed by reactions 2 and 5 are needed. Stocker (1978a, his reactions 7 and 11) considered explicit reactions by which silica could be exsolved from enstatite: 


$$
\begin{aligned}
& \mathrm{Si}_{\mathrm{Si}{ }^{\mathrm{x}}}+\mathrm{MgSiO}_{3}+1 / 2 \mathrm{O}_{2}=2 \mathrm{SiO}_{2}+\mathrm{Me}_{\mathrm{i}}^{*}+\mathrm{V}_{\mathrm{Si}}^{\cdots \cdots}+2 \mathrm{~h}^{\circ} \\
& \mathrm{MgSiO}_{3}=\mathrm{SiO}_{2}+1 / 2 \mathrm{O}_{2}+\mathrm{Me}_{\mathrm{i}}+2 \mathrm{e}^{\prime}
\end{aligned}
$$

Both reactions utilize cation interstitials, which are not majority defects in the electroneutrality regimes reepresented by equations 2 or 5 . This approach should be combined with Seebeck, electrical conductivity, creep, and electron microscopy measurements on different samples of the same diopside in an attempt to relate precipitation/consumption of silica to the electrical and mechanical property measurements.

\section{Conclusions}

Initially, the Rotkopschart diopside had an unusually negative Seebeck coefficient, indicating negative mobile change carriers (cation vacancies, electrons). At steady state, the Seebeck coefficient is insensitive to the ambient furnace $f_{2}$. Before equilibrium or steady state, an increase in $\mathrm{fO}_{2}$ causes an increase in the Seebeck coefficient (negative charges migrate to the cooler end of the diopside crystal), and vice versa. Models involving formation or consumption of majority carriers consisting of mobile cation vacancies and less mobile ferric iron sites can explain the time-dependent response of the Seebeck coefficient to changes in $\mathrm{fO}_{2}$. These models make use of different migration rates of species formed rather than appealing to reaction rates that vary with the number or nature of phases that react. The small dependence of electrical conductivity on $\mathrm{fO}_{2}$, measured only after the second series of diopside measurements, is consistent with a diopside that is in equilibrium with silica. The two series of measurements differ in the magnitude of the Seebeck coefficient, which was larger when a silica glass sleeve supported the metal wires leading from the diopside crystal. Whether or not the silica sleeve affected the defect population of the diopside is not known. Since the diopside recovered from 
accidentally imposed charge, a better experimental strategy would be to characterize the interface polarization (using impedance spectroscopy) and measure the $\mathrm{O}_{2}$-dependence of the electrical conductivity at the start and end of each set of Seebeck measurements.

Acknowledgements: Roberta Dillenburg recorded many of the profiles (time, oxygen-cell EMF, and thermoelectric power) and transcribed data into a spreadsheet for plotting figure 2. I-Ming Chou and Olivier Jaoul provided constructive technical reviews. The U.S. Geological Survey's Deep Continental Studies Program (later known as Continental Surveys Program) supported the research. 


\section{References}

Bauerle, J.E., Sutter, P.H., and Ure, R.W., Jr. (1961) Measurements of properties of thermoelectric materials. In Heikes, R.R. and Ure, R.W., Jr., Eds., Thermoelectricity: science and engineering. New York: Interscience Publishers, 285-338.

Bedford, R.E., Ma, C.K., Barber, C.R., Chandler, T.R., Quinn, J.T., Burns, G.W., and Scroger, M. (1972) New reference tables for platinum $10 \%$ rhodium/platinum and platinum $13 \%$ rhodium/platinum thermocouples. In Plumb, H.H., Ed., Temperature, Its Measurement and Control in Science and Industry, vol. 4, 1585-1602.

Burns, G.W., Scroger, M.G., Strouse, G.F., Croarkin, M.C., and Guthrie, W.F. (1993) Temperature-electromotive force reference functions and tables for the letter-designated thermocouple types based on the ITS-90. National Institute of Standards and Technologý, Monograph 175, 633 p.

Choi, G.M. (1983) Electrical conductivity and thermoelectric power studies in $\mathrm{Ba}_{0.3} \mathrm{Sr}_{0.7} \mathrm{TiO}_{3}$. M.S. Thesis, Department of Materials Science and Engineering, Massachusetts Institute of Technology, Cambridge, Massachusetts.

Christensen, Bruce J., Coverdale, R. Tate, Olsen, Rudolf A., Ford, Steven J., Garboczi, Edward J., Jennings, Hamlin M., and Mason, Thomas O. (1994) Impedance spectroscopy of hydrating cement-based materials: Measurement, interpretation, and application. Journal of the American Ceramic Society, 77, 2789-2804.

Cusack, N. and Kendall, P. (1958) The absolute scale of thermoelectric power at high temperatures. Physical Society of London, Institute of Physics and Physical Society Proceedings, 72, p. 898-901. 
Gasparik, T., and Lindsley, D.H. (1980) Phase equilibria at high pressures of pyroxenes containing monovalent and trivalent ions. In Prewitt, C.T., Ed., Reviews in Mineralogy, vol. 7: Pyroxenes, p. 309-339. Mineralogical Society of America, Washington, D.C.

Hodge, J.D. and Bowen, H.K. (1981) Time relaxation of the thermoelectric power of wustite. Journal of the American Ceramin Society, 64, C23-C24.

Hodge, J.D. and Bowen, H.K. (1982) Effect of thermal gradients on ionic defects in wustite. Journal of the American Ceramic Society, 65, p. 582-588.

Hsieh, G., Edwards, D.D., Ford, S.J., Hwang, J.-H., Shane, J., Garboczi, E.J., and Mason, T.J. (1996) Experimental limitations in impedance spectroscopy of materials systems. In Gerhardt, R.A., Taylor, S.R., and Garboczi, E.J., Eds., Electrically based Microstructural characterization. Materials Research Society Symposium Proceedings Volume 411, p. 312.

Huebner, J.S. (1987) Use of gas mixtures at low pressure to specify oxygen and other fugacities of furnace atmospheres. In G.C. Ulmer and H.L. Barnes, Eds., Hydrothermal experimental techniques, p. 20-60. Wiley, New York.

Huebner, J.S. and Dillenburg, R.G. (1995) Impedance spectra of hot, dry silicate minaerals and rock: Qualitative interpretation of spectra. The American Mineralogist, 80, 46-64.

Huebner, J.S. and Voigt, D.E. (1988) Electrical conductivity of diopside: Evidence for oxygen vacancies. The American Mineralogist, 73, 1235-1254.

Huebner, J.S. and Woodruff, M.E. (1985) Chemical compositions and critical evaluation of microprobe standards available in the Reston Microprobe Facility. U.S. Geological Survey Open File Report 85-718, 276 p. 
Ingrin, J., Doukhan, N., and Doukhan, J.C. (1991) High temperature deformation of diopside single crystal, 2. TEM investigation of the induced defect microstructures. Journal of Geophysical Research, 96, 14287-14297.

Jaoul, O., and Raterron, P. (1994) High-temperature deformation of diopside crystal 3. Influences of $p \mathrm{O}_{2}$ and $\mathrm{SiO}_{2}$ precipitation. Journal of Geophysical Research, 99, 94239439.

Mason, T.O. (1987) Cation intersite distributions in iron-bearing minerals via electrical conductivity/Seebeck effect. Physics and Chemistry of Minerals, 14, 156-162.

Nyström, J. (1957) Thomson coefficients for copper at high temperatures. Arkiv för Matematik, Astronomi och Fysik, 34a, 1-27.

Schock, R.N., Duba, A.G., and Shankland, T.J. (1989) Electrical conduction in olivine. Journal of Geopgysical Research, 94, 5829-5839.

Stocker, R.L. (1978a) Variation of electrical conductivity in enstatite with oxygen partial pressure: comparison of observed and predicted behavior. Physics of the Earth and Planetary Interiors, 17, p. P34-P40.

Stocker, R.L. (1978b) Point defect formation parameters in olivine. Physics of the Earth and Planetary Interiors, 17, p. 108-117.

Stocker, R.L. (1978c) Influence of oxygen pressure on defect concentrations in olivine with a fixed cationic ratio. Physics of the Earth and Planetary Interiors, 17, p. 118-129.

Stocker, R.L. and Smyth, D.M. (1978) Effect of enstatite activity and oxygen pressure on the point-defect chemistry of olivine. Physics of the Earth and Planetary Interiors, 16, p. 145156. 
Tuller, H.L. (1985) Electrical conduction in ceramics. In Schock, R.N., Ed., Point Defects in Minerals, American Geophysical Union Geophysical Monograph 31, 47-68.

Tuller, H.L., Yoo, H.I., Kehr, W., and Scheidecker, R.W. (1986) Electrical property - phase equilibria in manganese-zinc ferrites. Advances in Ceramics, 15, 315-324.

Wanamaker, B.J. (1994) Point defect diffusivities in San Carlos olivine derived from reequilibration of electrical conductivity following changes in oxygen fugacity. Geophysical Research Letters, 21, 21-24.

Wimmer, J.M. and Bransky, I. (1974) Electronic conduction. In Tallan, N.M., Ed., Electrical conductivity in ceramics and glass, Part A. New York: Marcel Dekker, 270-311. 
Table 1. Electron Microprobe chemical analysis of diopside*

Weight $\% \quad$ Cations/6 oxygens

\begin{tabular}{|c|c|c|}
\hline $\mathrm{SiO}_{2}$ & 55.11 & 1.994 \\
\hline $\mathrm{P}_{2} \mathrm{O}_{5}$ & 0.013 & 0.0004 \\
\hline $\mathrm{Al}_{2} \mathrm{O}_{3}$ & 0.055 & 0.0023 \\
\hline $\mathrm{TiO}_{2}$ & 0.010 & 0.0003 \\
\hline $\mathrm{MgO}$ & 17.73 & 0.956 \\
\hline $\mathrm{Cr}_{2} \mathrm{O}_{3}$ & 0.008 & 0.0002 \\
\hline $\mathrm{Fe}_{2} \mathrm{O}_{3}$ & 0.335 & 0.009 \\
\hline $\mathrm{FeO}$ & 1.48 & 0.045 \\
\hline $\mathrm{NiO}$ & 0.009, & 0.0003 \\
\hline $\mathrm{MnO}$ & 0.198 & 0.0061 \\
\hline $\mathrm{ZnO}$ & 0.069 & 0.0018 \\
\hline $\mathrm{CaO}$ & 25.36 & 0.983 \\
\hline $\mathrm{Na}_{2} \mathrm{O}$ & 0.019 & 0.0013 \\
\hline Total & 100.40 & 4.000 \\
\hline
\end{tabular}

* Average of 44 spot analyses, obtained during two operating shifts, recalculated as explained in text. Standards were as follows: $\mathrm{Si}, \mathrm{Ca}=\mathrm{PXP} 1 ; \mathrm{P}=\mathrm{APFD} ; \mathrm{Al}, \mathrm{Ti}, \mathrm{Na}=\mathrm{AMKH} ; \mathrm{MG}=$ PXEN; $\mathrm{Cr}=\mathrm{OXTB} ; \mathrm{Fe}=\mathrm{PXHD} ; \mathrm{Ni}=\mathrm{OLNI}$; $\mathrm{Mn}=\mathrm{OLST}$; and $\mathrm{Zn}=\mathrm{OXGH}$ (see Huebner and Woodruff, 1985). 
Table 2. Chronological Summary of $\mathrm{Q}(-\mathrm{mV} / \mathrm{K})$ for Diopside Surrounded by Silica Glass Sleeve $(\Delta K=1.5-4.9 \mathrm{~K})$

\begin{tabular}{|c|c|c|c|c|c|c|c|c|c|}
\hline${ }^{\circ} \mathrm{C}$ & $\log \mathrm{fO}_{2}$ & $T_{\text {hot }}$ & $\Delta T$ & $Q_{\text {init }}$ & $\log \mathrm{fO}_{2}$ & $\mathrm{Q}_{\min / \max }$ & $Q_{\text {final }}$ & time, s & Comments \\
\hline 883 & -13.9 & 879 & 4.56 & & & & -5.7 & $1.7 \times 10^{5}$ & Initial conditions \\
\hline 1000 & -12.00 & 995 & 2.40 & & & & -9.9 & $8.2 \times 10^{4}$ & Changed temperature and $\mathrm{fO}_{2}$ \\
\hline 1000 & -14.48 & 995 & 2.42 & -6.6 & -10.02 & & -14. & $8.7 \times 10^{4}$ & Changed $f_{2}, Q=-17.3$ at $3480 \mathrm{~s}$ \\
\hline 1000 & -9.55 & 994 & 2.35 & & & & -13. & $1.7 \times 10^{4}$ & Changed $\mathrm{fO}_{2}$ \\
\hline 1001 & -11.0 & 994 & 2.35 & & & & -8.6 & $6.3 \times 10^{4}$ & Changed $\mathrm{fO}_{2}$ \\
\hline 1000 & -15.48 & 993 & 2.50 & & & & -7.0 & $7.3 \times 10^{4}$ & Changed $\mathrm{fO}_{2}$ \\
\hline 1000 & -13.00 & 993 & 2.72 & & & & -7.5 & $1.9 \times 10^{4}$ & Changed $\mathrm{fO}_{2}$ \\
\hline 1000 & -11.49 & 993 & 2.80 & & & & -6.4 & $2.5 \times 10^{5}$ & Changed $\mathrm{fo}_{2}$ \\
\hline 1000 & -10.58 & 993 & 2.70 & & & & -7.5 & $6.3 \times 10^{4}$ & Changed $\mathrm{fO}_{2}$ \\
\hline 1000 & -9.5 & 992 & 2.56 & & & & -8.4 & $8.6 \times 10^{4}$ & Changed $f \mathrm{O}_{2}, Q=-11.8$ at $12840 \mathrm{sec}$ \\
\hline 1001 & -2.7 & 995 & 2.66 & & & & & & Changed $f \mathrm{O}_{2}, \mathrm{Q}=-13.8$ at $2820 \mathrm{~s}$ \\
\hline 1000 & -2.7 & & 2.91 & & & & -1.4 & $7.7 \times 10^{4}$ & $Q=-10.2$ at $11460 \mathrm{~s}$ \\
\hline 1000 & -13.85 & 996 & 2.72 & & & & -4.3 & $1.1 \times 10^{5}$ & Changed $\mathrm{fO}_{2}$ \\
\hline 1000 & -10.70 & 994 & 2.54 & & & & -6.4 & $2.4 \times 10^{5}$ & Changed $f_{2}, Q=-13.6$ at $1680 \mathrm{sec}$ \\
\hline 1000 & -10.77 & 994 & 2.46 & -6.4 & -13.85 & +3.9 & -4.2 & $7.5 \times 10^{5}$ & $Q_{\max }$ at $1260 \mathrm{~s}$, steady state not reached \\
\hline 1000 & -13.85 & 994 & 2.46 & -4.2 & -10.74 & -14.9 & -7.7 & $8.0 \times 10^{4}$ & $\mathrm{Q}_{\min }$ at $3720 \mathrm{~s}$, steady state not reached \\
\hline 1000 & -10.72 & & 2.46 & -7.7 & -13.85 & +3.7 & -3.8 & $8.6 \times 10^{4}$ & $\mathrm{Q}_{\max }$ at $1440 \mathrm{~s}$ \\
\hline 900 & -15.87 & 892 & 3.48 & -0.5 & -12.71 & -11.4 & & & $Q_{\min }$ at $4080 \mathrm{~s}$, power outage at $16020 \mathrm{~s}$ \\
\hline 900 & -12.54 & 894 & 3.67 & -3.6 & -15.89 & +7.4 & -0.89 & $1.3 \times 10^{6}$ & $\mathrm{Q}_{\max }$ at $1680 \mathrm{~s}$ \\
\hline 900 & -15.89 & 894 & 3.32 & -1.0 & -12.70 & -12. & & $9.6 \times 10^{4}$ & $Q_{\min }$ at $6000 \mathrm{~s}$, last $Q=-7.5$ \\
\hline 899 & -12.74 & 894 & 3.40 & -3.2 & -15.96 & +6.6 & -0.79 & $3.4 \times 10^{5}$ & $Q_{\max }$ at $1740 \mathrm{~s}$ \\
\hline 900 & -15.96 & 895 & 3.25 & -2.6 & -12.71 & -12.3 & -2.4 & $1.4 \times 10^{6}$ & $\mathrm{Q}_{\min }$ at $4200 \mathrm{~s}$ \\
\hline 1001 & -10.74 & 994 & 2.61 & -10.0 & -13.82 & +4.2 & -5.6 & $4.4 \times 10^{5}$ & $Q_{\max }$ at $1410 \mathrm{~s}$ \\
\hline 1000 & -13.85 & 994 & 2.52 & -5.6 & -10.70 & -15.4 & -6.7 & $5.2 \times 10^{5}$ & $Q_{\min }$ at $2700 \mathrm{~s}$ \\
\hline 1100 & -9.14 & 1093 & 1.63 & & -9.16 & & & $1.1 \times 10^{6}$ & $Q$ varies, $-8.2 \rightarrow-4.7 \rightarrow-12.0 \rightarrow-8.0$ \\
\hline 1098 & -9.16 & 1092 & 1.85 & -8.0 & -12.16 & -0.41 & -12.7 & $2.6 \times 10^{5}$ & $\mathrm{Q}_{\min }$ at $840 \mathrm{~s}$ \\
\hline 1098 & -12.15 & 1092 & 1.74 & & & & -22. & $1.6 \times 10^{4}$ & $Q$ decreased \\
\hline 1098 & -12.16 & 1093 & 1.69 & & & & -5.9 & $2.0 \times 10^{4}$ & $Q$ increased \\
\hline 1100 & -12.16 & 1093 & 1.88 & -11. & -9.06 & -14.4 & -8.4 & $2.8 \times 10^{5}$ & $Q_{\min }$ at $1170 \mathrm{~s}$ \\
\hline 1098 & -9.02 & 1093 & 1.61 & -10. & -12.15 & -3.0 & -12. & $9.8 \times 10^{4}$ & $Q_{\max }$ at $1860 \mathrm{~s}$ \\
\hline 1098 & -12.16 & 1093 & 1.71 & & & & & $2.0 \times 10^{5}$ & $Q$ varies, -9.3 to -11.3 \\
\hline 1097 & -12.17 & 1092 & 2.00 & & & & & $2.0 \times 10^{5}$ & $Q$ varies, -2.1 to -4.3 \\
\hline
\end{tabular}


Table 3. Chronological Summary of $Q$ (-mV/K) for Silica Glass Sleeve $(\Delta K=49-62 K)$

$\begin{array}{llllllllll}{ }^{\circ} \mathrm{C} \text { Cell } & \log f \mathrm{f}_{2} & \mathrm{~T}_{\text {hot }} & \mathrm{T}_{\text {cool }} & \mathrm{Q}_{\text {init }} & \log f \mathrm{f}_{2} & \mathrm{Q}_{\min / \max } \mathrm{Q}_{\text {final }} & \text { time, s } & \text { Comments } \\ 785 & -13.9 & 784 & 722 & 0.16 & -11.3 & & & & \text { Not yet equilibrated? } \\ 995 & -11.9 & 993 & 939 & -1.6 & -11.9 & & & & \text { Not yet equilibrated? } \\ 1000 & -11.88 & 995 & 944 & 0.45 & -11.82 & & & & \text { Positive charge carriers } \\ 1000 & -11.82 & 996 & 944 & 0.66 & -11.81 & & & & \\ 1000 & -11.81 & 996 & 944 & 0.64 & -10.39 & 0.50 & 0.59 & 7.3 \times 10^{4} & \text { Min at } 1620 \text { seconds } \\ 1000 & -10.39 & 996 & 944 & 0.64 & -13.28 & 0.54,0.750 .65 & 1.4 \times 10^{4} & \text { Min at } 120, \text { Max at } 1680 \mathrm{~s} \\ 1000 & -13.36 & 996 & 944 & 0.83 & & & & & \\ 1000 & -13.42 & 997 & 945 & 0.64 & -10.45 & 0.39 & 0.70 & 7.7 \times 10^{4} & \text { Minimum at } 1500 \text { sec } \\ 1100 & -8.96 & 1096 & 1048 & 0.27 & & & & & \\ 1100 & -8.95 & 1096 & 1047 & 0.17 & -11.98 & 0.42 & 0.32 & 4.3 \times 10^{3} & \text { Maximum at 720 sec } \\ 1100 & -11.98 & 1095 & 1047 & 0.32 & -10.17 & 0.37 & 0.29 & 7.2 \times 10^{4} & \text { Max at 300 seconds } \\ 1099 & -10.17 & 1095 & 1046 & -0.15 & & & & & \text { Negative charge carriers } \\ 905 & -12.79 & 901 & 844 & -0.12 & & & & & \text { Negative charge carriers } \\ 900 & -12.80 & 897 & 838 & 0.19 & & & & & \text { Positive charge carriers } \\ 900 & -12.73 & & & 0.33 & & & & & \text { DMM, Electrometer agree } \\ 900 & -11.58 & 898 & 840 & 0.69 & & & & & \text { DMM 3 weeks late, new CO }{ }_{2} \\ 900 & -11.59 & 897 & 840 & 0.69 & -13.27 & 0.58 & 0.72 & 4.3 \times 10^{3} & \text { Minimum at 330 sec } \\ 1000 & -13.31 & 997 & 944 & 0.64 & -11.52 & 0.71 & 0.64 & 9.5 \times 10^{3} & \text { Maximum at } 540 \text { sec } \\ 1100 & -10.15 & 1096 & 1047 & 0.67 & & & & & \\ 1100 & -10.15 & 1096 & 1046 & 0.57 & & & & & \\ 1100 & -10.15 & 1096 & 1046 & 0.57 & -10.19 & & 0.33 & 8.1 \times 10^{4} & \text { New CO, Q decreased } \\ 1100 & -10.19 & 1096 & 1046 & +20 . & -10.19 & & 0.34 & 7.0 \times 10^{4} & \text { Decay of applied DCV } \\ 1100 & -10.21 & 1096 & 1046 & -18 . & -10.20 & & 0.29 & 1.6 \times 10^{4} & \text { Decay of applied DCV } \\ 1100 & -10.20 & 1096 & 1046 & 0.31 & -12.01 & 0.22 & 0.43 & 7.9 \times 10^{4} & \\ 1100 & -12.01 & 1096 & 1047 & 0.43 & -10.21 & 0.56 & 0.36 & 8.1 \times 10^{4} & \end{array}$


Table 4. Chronological Summary of $Q(-m V / K)$ for Diopside $(\Delta K=14-18 \mathrm{~K})$

\begin{tabular}{|c|c|c|c|c|c|c|c|c|c|}
\hline${ }^{\circ} \mathrm{C}$ Cell & $\log \mathrm{fO}_{2}$ & $T_{\text {hot }}$ & $\mathrm{T}_{\text {cool }}$ & $Q_{\text {init }} \log$ & $\mathrm{g} \mathrm{fo}_{2}$ & $Q_{\min / \max }$ & $Q_{\text {final }}$ & time, $s$ & Comments \\
\hline 850 & -13.30 & 843 & 828 & -1.10 & & & & & Negative charge carriers \\
\hline 1000 & -11.68 & 992 & 978 & -0.42 & & & & & Negative charge carriers \\
\hline 1000 & -11.68 & 992 & 978 & -21 & -11.68 & & +0.81 & $5.8 \times 10^{4}$ & DCV applied, decayed \\
\hline 1000 & -11.68 & 993 & 979 & +18 & -11.68 & & +0.23 & $2.7 \times 10^{5}$ & DCV applied, decayed \\
\hline 1000 & -11.68 & 994 & 980 & -0.05 & & & & & \\
\hline 1000 & -11.68 & 994 & 980 & +0.7 & -13.54 & +3.24 & +0.06 & $8.3 \times 10^{4}$ & Maximum at 660 seconds \\
\hline 1000 & -13.54 & 994 & 980 & +0.06 & -11.72 & -3.33 & -0.13 & $1.0 \times 10^{5}$ & Minimum at 1110 seconds \\
\hline 1000 & -11.70 & 994 & 980 & +0.32 & & & & & Positive charge carriers \\
\hline 1000 & -11.69 & 994 & 980 & +0.07 & & & & & \\
\hline 1000 & -11.69 & 994 & 980 & +0.58 & & & & & \\
\hline 1000 & -11.69 & 992 & 974 & $\approx 0$ & & & & & \\
\hline 1100 & -10.17 & 1091 & 1074 & -0.39 & & & & & Negative charge carriers \\
\hline 1100 & -10.22 & 1091 & 1074 & -0.20 & & & & & \\
\hline 1100 & -10.23 & 1091 & 1074 & -0.13 & -12.03 & +2.06 & & & Maximum at 690 seconds \\
\hline 1100 & -12.03 & 1091 & 1074 & +8.3 & -12.03 & & -0.08 & & DCV applied, decayed \\
\hline 1100 & -11.61 & 1091 & 1074 & -0.08 & -10.24 & -2.52 & -0.12 & $8.1 \times 10^{4}$ & Minimum at 720 seconds \\
\hline 1100 & -10.24 & 1091 & . 1074 & -0.12 & -8.68 & -1.98 & & & Minimum at 900 seconds \\
\hline 1101 & -8.68 & 1091 & 1074 & -139 & -8.68 & & -0.63 & $3.5 \times 10^{3}$ & DCV applied, decayed \\
\hline 1101 & -8.68 & 1091 & 1074 & -17.5 & -8.68 & & -0.13 & $1.1 \times 10^{5}$ & DCV applied, decayed \\
\hline 1100 & -8.68 & 1091 & 1074 & -0.16 & -12.81 & +4.57 & -0.17 & $7.0 \times 10^{4}$ & Maximum at 600 seconds \\
\hline
\end{tabular}


Table 5. Some possible point defects in diopside.

\begin{tabular}{|c|c|c|c|}
\hline Species* & $f_{2}$-dependence & Favorable energy? & References \\
\hline $\mathrm{V}_{\mathrm{me}}^{\prime \prime}$ & + & Yes & $1,2,3$ \\
\hline$e^{\prime}$ & - & yes & 2 \\
\hline $\mathrm{Me}_{1}$ & - & yes & $1,2,3$ \\
\hline $\mathrm{Si}_{1} \cdots$ & - & yes & 2,3 \\
\hline $\mathrm{Fe}_{\mathrm{Me}}^{\dot{ }}$ & + & yes & 2,3 \\
\hline $\mathrm{Fs}_{1}$.* & - & yes & 2,3 \\
\hline $\mathrm{Fc}_{1}{ }^{\ldots \ldots}$ & varies & varies & 2 \\
\hline$v_{0}{ }^{\circ}$ & , & yes & 2,3 \\
\hline$v_{0} \ddot{ }$ & - & yes & 2,3 \\
\hline$v_{\mathrm{si}}{ }^{\prime \prime \prime \prime \prime \prime}$ & + & no & $1,2,3$ \\
\hline$\partial_{1}^{\prime \prime}$ & + & no & $1,2,3$ \\
\hline • & + & no & 1,2 \\
\hline
\end{tabular}

\footnotetext{
${ }^{*} M e=M(1)$ site, normally occupied by $M g$ and Fe species; Ca assumed to fully occupy $M(2)$ Fs = divalent iron

$\mathrm{Fc}=$ trivalent iron
}
(1) Stocker (1978a) on enstatite
(2) Stocker (1978b) on olivine
(3) Stocker and Smyth (1978) on olivine 


\section{Figure Captions}

Figure 1. Sketch of sample (dashed) and wire-lead configuration. The silica glass sleeve that surrounds but does not touch the diopside crystal is not shown. $T_{h}>T_{c}>T_{i p}=0^{\circ} \mathrm{C}$. The thermoelectric EMF, $V_{m}$, is measured between leads $A$ and $D$; the contributions of the various parts of the circuit to $V_{m}$ are discussed in the text. Temperatures are measured using leads $\mathrm{A}$ and $\mathrm{B}$ (hot end of sample) and $\mathrm{C}$ and $\mathrm{D}$ (cool end). $\mathrm{T}_{\mathrm{ip}}$ is the ice bath at $0^{\circ} \mathrm{C}$.

Figure 2. Response of thermoelectric power coefficient $\mathrm{Q}$, at $1000{ }^{\circ} \mathrm{C}$, to changes in oxygen fugacity. Cell EMF (open squares) is the measured EMF of the doped-zirconia oxygen sensor; more negative values represent lower values of $f_{\mathrm{O}_{2}}$. Filled triangles are values of Q (plotted as -Q). (a) $\log f_{\mathrm{O}_{2}}$ raised from -13.8 to $-10.7 \log$ bar units. The sign of $\mathrm{Q}$, and thus of the dominant charge carrier, is negative throughout. (b) $\log f_{\mathrm{O}_{2}}$ changed from -10.7 to $-13.8 \mathrm{log}$-bar units. The sign of the dominant charge carrier is positive for a short time soon after the $f_{\mathrm{O}_{2}}$ is decreased. The final value of $\mathrm{Q}$ is insensitive to the final value of $\mathrm{fo}_{2}$.

Figure 3. Temperature dependence of $Q$ at 900,1000 , and $1100{ }^{\circ} \mathrm{C}$. Filled rectangles indicate values of $\mathrm{Q}$ following an increase in $f_{2}$; open rectangles indicate values of $\mathrm{Q}$ following a decrease in $f_{\mathrm{O}_{2}}$. Small ovals represent measurements that are not associated with changes in $f_{\mathrm{O}_{2}}$; most represent early readings, before the short-terms response of $\mathrm{Q}$ was recognized. Straight line is the linear regression of the open and filled rectangles.

Figure 4. Impedance spectra of diopside at $1000^{\circ} \mathrm{C}$ plotted in the complex plane. Frequency increases to the left. For each spectrum, the broad, upright, left arc is the response of the sample interior and the small, depressed, rightmost right arc indicates passage of charge carriers between the diopside and the $\mathrm{Pt}$ wire electrodes. Squares and circles, $f_{\mathrm{O}_{2}}=10^{-12.8}$; diamonds and upright triangles, $f_{\mathrm{O}_{2}}=10^{-8.7}$; inverted triangles, open circuit. (a) Raw impedance data; (b) impedance data following nulling using the open circuit spectrum (which has the same values in both parts of the figure).

Figure 5. Highly schematic diagram showing the time-dependent response of the Rotkopschart diopside's Seebeck coefficient to changes in $f_{2}$, according to reaction 5. The "background" of negative charge carriers, measured at steady state, is not portrayed. X signifies the additional defects formed at the hot end, relative to the cooler end of the sample; $\mathrm{Y}$ signifies the proportion of the $\mathrm{X}$ defects that migrate to the cooler end. 
Figure 1

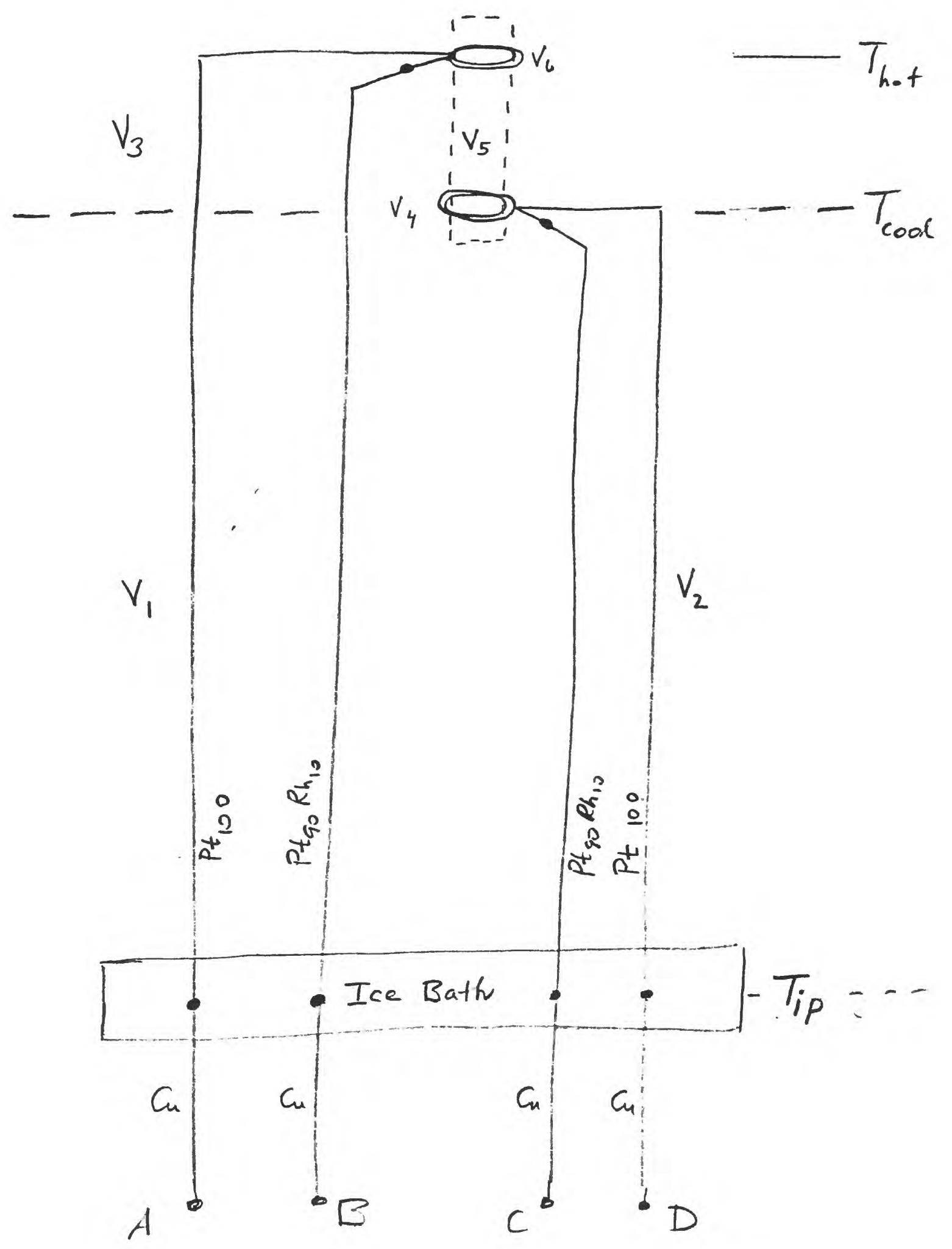

36 
Figure $2 a$

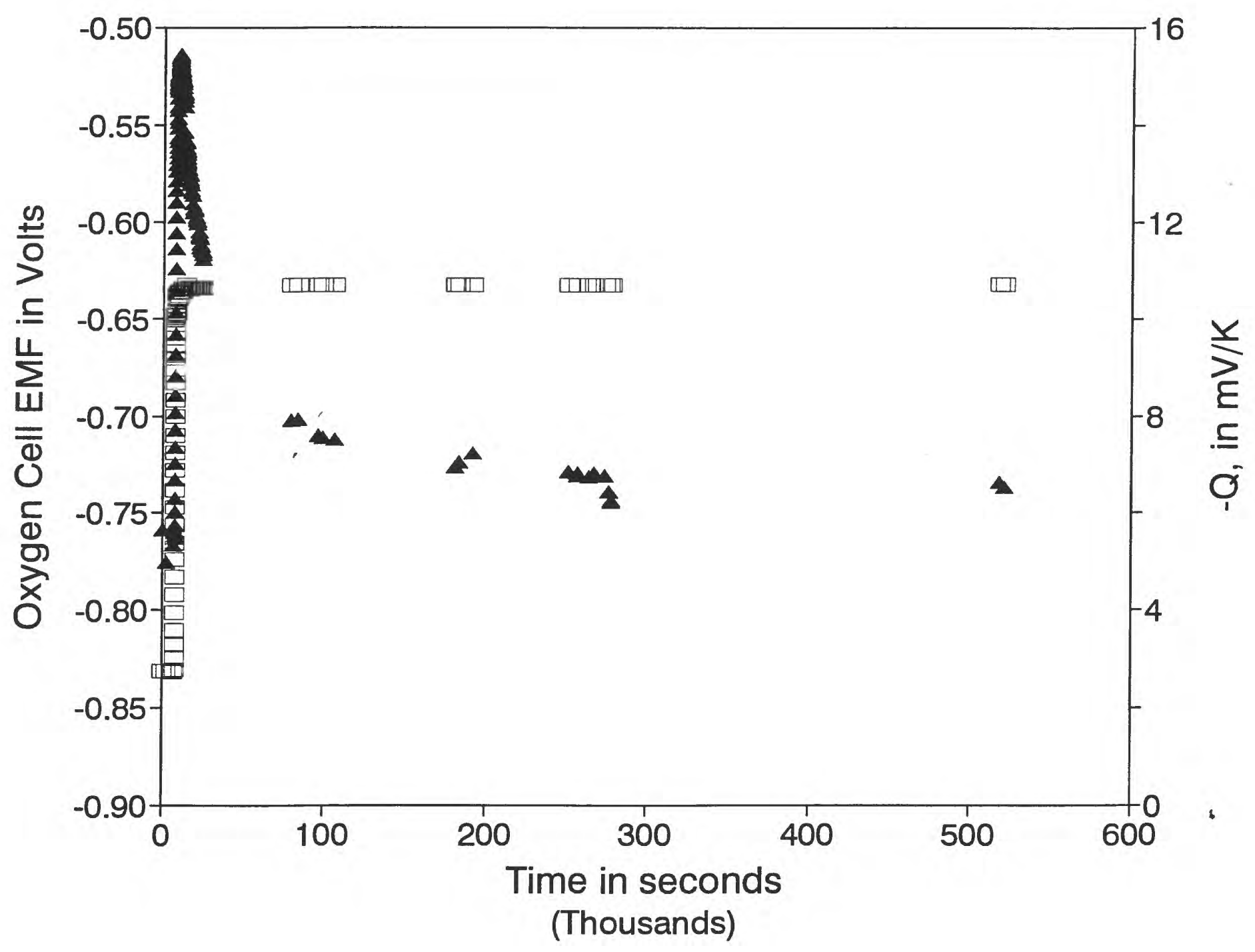


Fiqure $2 b$

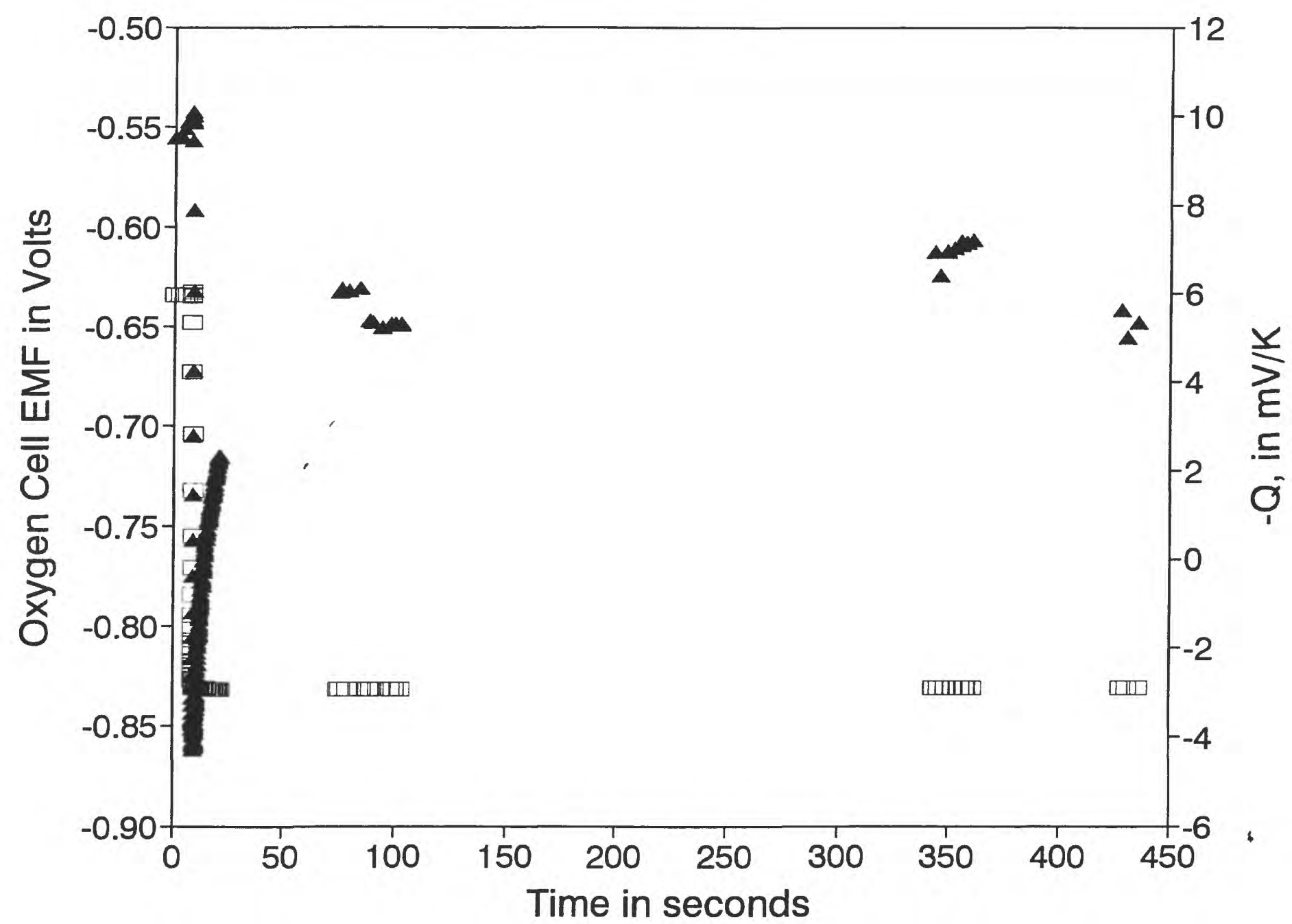

(Thousands) 
Figure 3

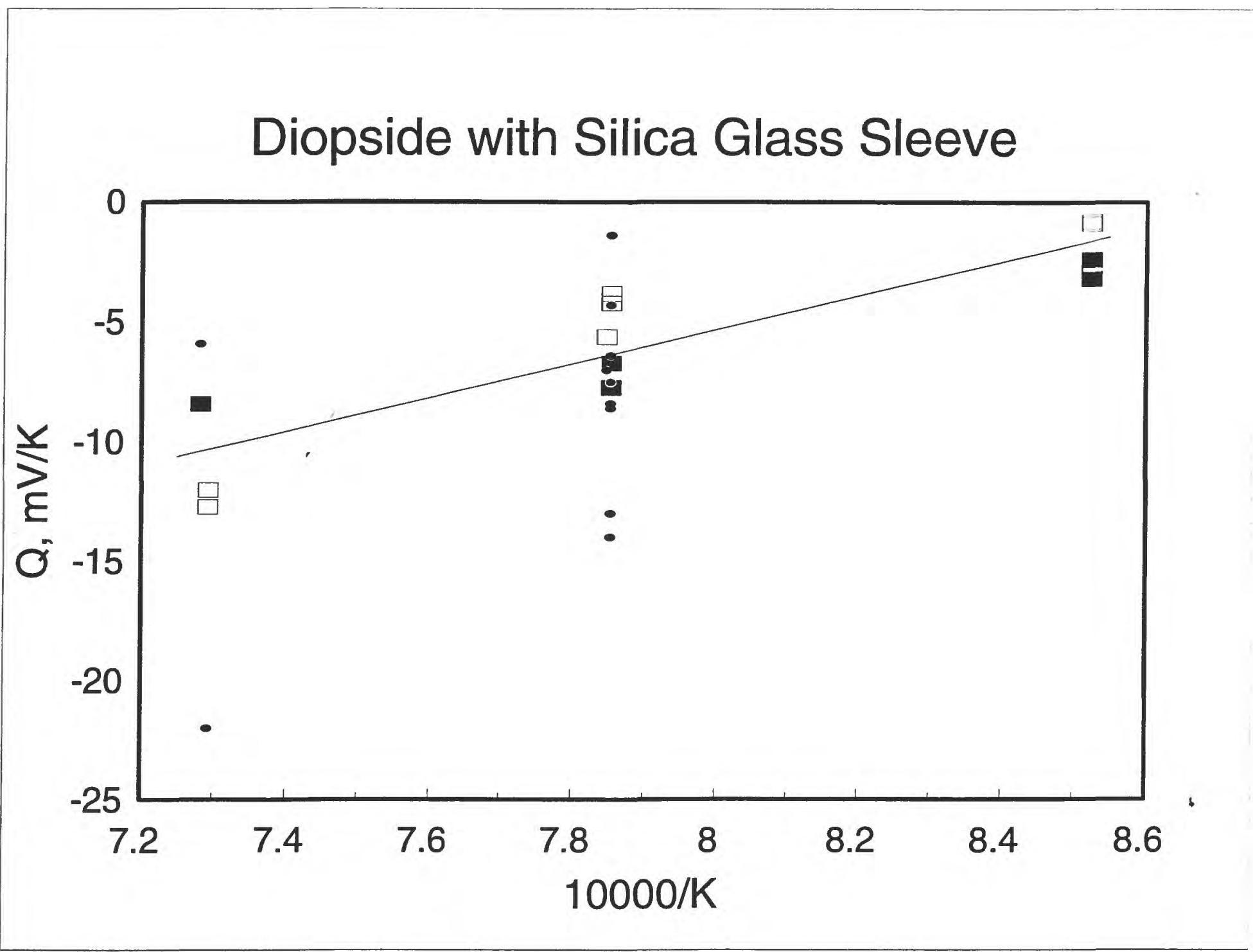


Figure 4
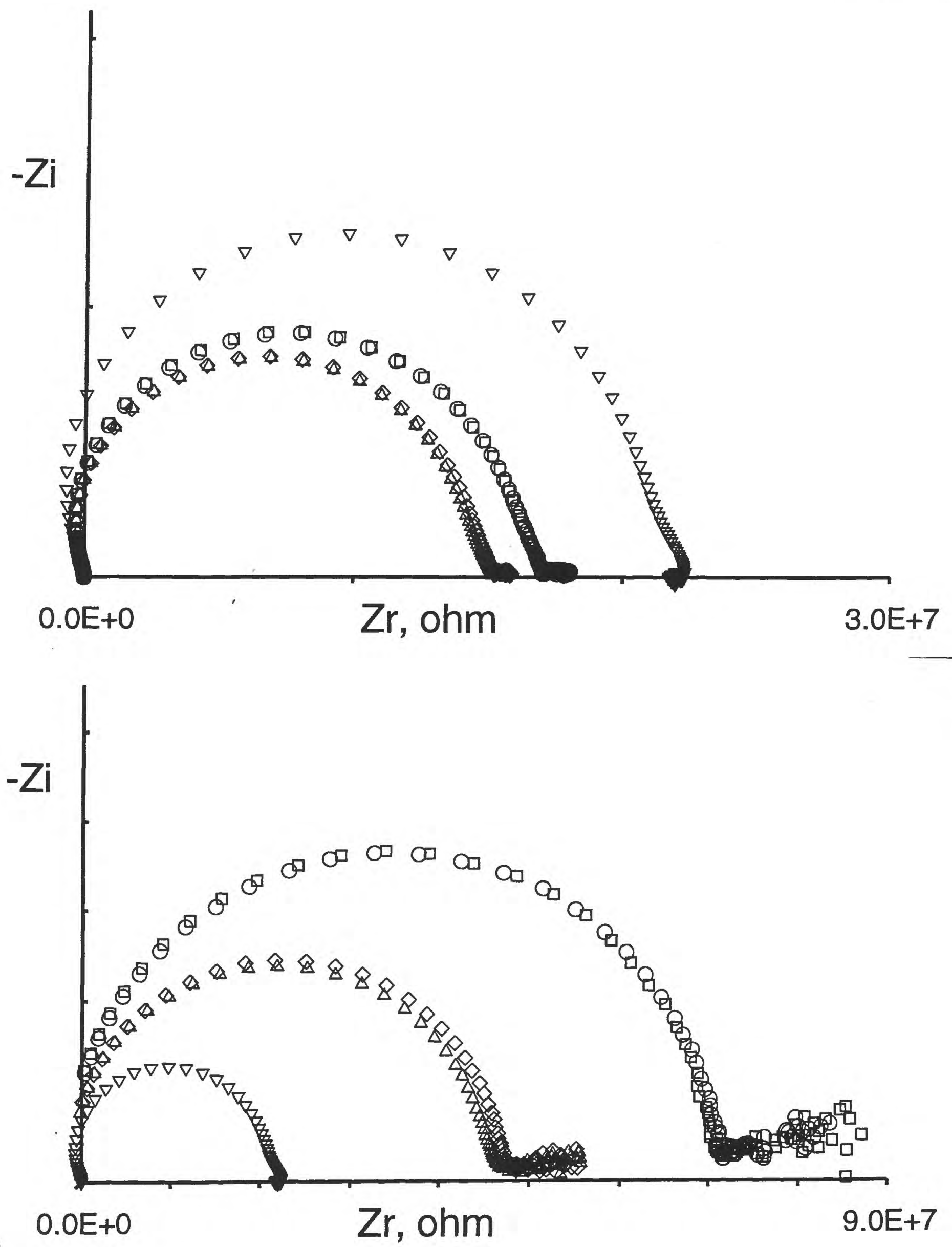
Figure 5
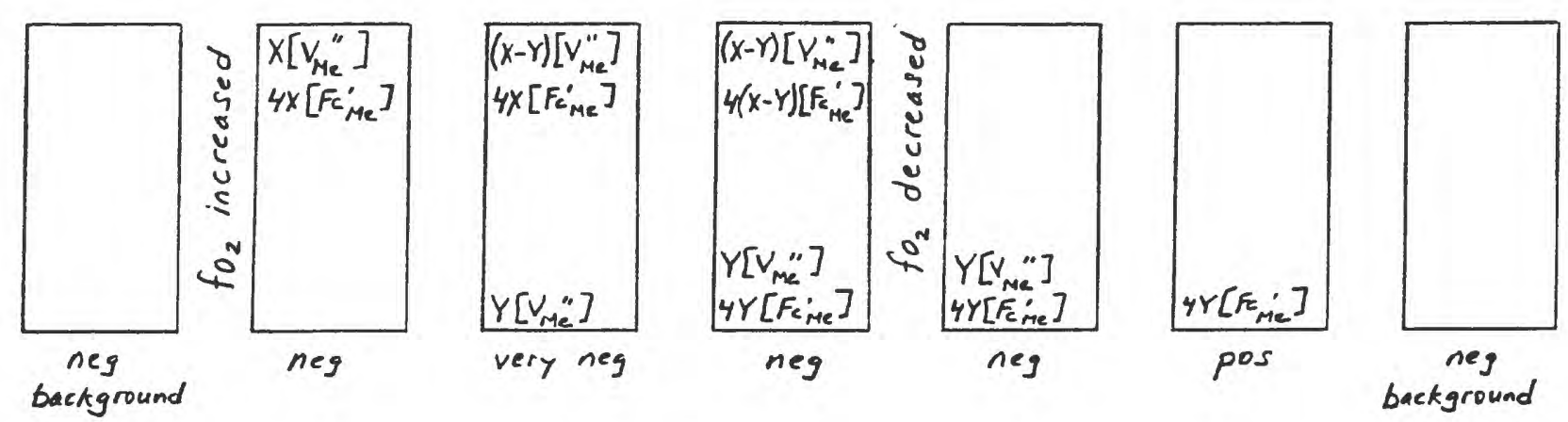

time 